\title{
BOARD OF DIRECTOR'S GENDER DIVERSITY AND ITS IMPACT ON EARNINGS MANAGEMENT: AN EMPIRICAL ANALYSIS FOR SELECT EUROPEAN FIRMS
}

\author{
Paolo SAONA ${ }^{1}$, Laura MURO ${ }^{1}$, Pablo SAN MARTÍN ${ }^{2}$, Hugo BAIER-FUENTES ${ }^{*}$ \\ ${ }^{1}$ Saint Louis University, Madrid Campus, Richard A. Chaifetz School of Business, \\ Avenida del Valle 34, 28003 Madrid, Spain \\ ${ }^{2}$ Universidad Católica de la Santísima Concepción, Facultad de Ciencias Económicas \\ y Administrativas, Alonso de Ribera 2850, Concepción, Chile
}

Received 12 June 2018; accepted 04 November 2018

\begin{abstract}
From a corporate governance point of view, this paper addresses the question about how board gender diversity influences managerial opportunistic behavior for solving agency conflicts from a sample of European countries. Specifically, we analyzed indexed non-financial companies from Denmark, Finland, France, Germany, Italy, Norway, Portugal, Spain, Sweden, and United Kingdom for the period 2006-2016. Several panel data techniques are used in the empirical analysis to deal with the endogeneity and heterogeneity problems. To the best of our knowledge our research is novel in the literature by providing a multi-country approach in board gender diversity, as well as considering contextual country variables and the role of the regulatory system as determinants of earnings management.

Our results confirm the benefits of having a balanced board in terms of gender diversity. An equilibrated board tends to mitigate earnings management practices, reinforcing the value of the laws passed in recent decades in Europe. Our analysis reveals that the regulatory framework regarding board gender diversity established by each country has a determinant role in reaching equality in decision-making positions, as a founding value of the European Union. We provide several policy recommendations from our main findings.
\end{abstract}

Keywords: earnings management, corporate governance, gender diversity, board composition, female quotas.

JEL Classification: G32, G34.

\section{Introduction}

Equality between women and men is one of the European Union's founding values. It goes back to 1957 when the principle of equal pay for equal work became part of the Treaty of Rome. In this respect, the European Commission has proposed legislations aimed at attaining

*Corresponding author. E-mail: hbaier@ucsc.cl

Copyright (C) 2019 The Author(s). Published by VGTU Press

This is an Open Access article distributed under the terms of the Creative Commons Attribution License (http://creativecommons. org/licenses/by/4.0/), which permits unrestricted use, distribution, and reproduction in any medium, provided the original author and source are credited. 
a $40.00 \%$ objective of the under-represented sex in non-executive board-member positions in publicly listed companies, with exceptions for small and medium enterprises. The proposed directive is supported by the European Parliament and by most member states and continues to be discussed in the Council of the European Union. As a matter of fact, at the European Union level, the share of women on the boards of large publicly listed companies has risen from $11.90 \%$ in October 2010 to $23.90 \%$ in October 2016 according to the European Institute for Gender Equality.

Equal participation of women and men in decision-making positions is a matter of justice, respect for fundamental rights, and good governance. However, there is not gender equality in decision making positions in the European Union according to the European Institute for Gender Equality. Concerning the female behavior, research has found that women are more risk averse and more conservative in their decisions (Cohn, Lewellen, Lease, \& Schlarbaum, 1975; Riley Jr. \& Chow, 1992). For instance, Byrnes, Miller, and Schafer (1999) conducted a meta-analysis of 150 studies in which the risk-taking tendencies of male and female participants were compared and found significant support for the proposition that women, on average, are more cautious and less aggressive than men in a variety of decision contexts. Hence, this differential behavior of female directors might impact the way boards make decisions.

Concerning the board's main role, there is a widely held concern about its inability to ensure that management acts in the interest of stakeholders (Huang, Chan, Chang, \& Wong, 2012). This can be observed in the substantial amount of real-life corporate scandals caused by misreporting financial information in which managers did not make decisions in the best interest of stakeholders, with the subsequent negative consequences on the image and reputation of companies. Hence, the role of the board of directors as a monitoring body of managers is critical in preventing managerial opportunistic behavior. Examples of corporate scandals dominated by firms that reported manipulated financial information across Europe include, among many others, Afinsa, Banesto, Gescartera and Pescanova, in the Spanish corporate sector; The Bank of Credit and Commerce International, Olympus and Tesco in the UK; ABB, Prosolvia and Fermenta from Sweden; Balsam and Comroad in Germany; Parmalat in Italy, and Kone in Finland. All these cases revealed the necessity to reinforce the rules and regulations towards a more transparent disclosure of financial statements. In most of these corporate scandals, managers misused their decision-making power and overstated the financial reports to realize private benefits before passive and ineffective boards of directors.

As females are more risk averse than males and more conservative in their financial decisions, this study intends to investigate if an increase of the presence of women in the board of directors brings more quality in the preparation of the financial statements and a smaller amount of earnings management. Hence, this paper empirically examines how board gender diversity influences the managerial opportunistic behavior materialized in the management of accounting earnings of firms listed on the main stock market indexes of ten European countries.

The most common way to misreport the real financial information is by using earnings manipulation. To constrain such opportunistic behavior, country-level initiatives have been implemented through enhanced regulation such as the Cadbury report in the UK in 1992 or the Good Governance Code of listed companies in Spain in 2006. Similarly, concerning 
specifically the board diversity, many European countries like Spain, Sweden, Denmark, Finland and the UK have enacted regulation towards mandating/promoting more female representation in publicly held firms (Sila, Gonzalez, \& Hagendorff, 2016). Norway is counted as the first European country to introduce legislation on gender quotas on the board of directors, including sanctions imposed when companies do not fulfill the required quotas. Italy, Germany, France and more recently Portugal have followed the example of Norway in this regard.

This paper contributes to the current literature from different angles. First, to the best of our knowledge, ours is a ground-breaking research in studying the impact of board gender diversity on earnings management for a multi-country sample of European firms. Second, we are also novel in the literature by considering contextual, country variables in the empirical analysis to shed additional light on the role played by the regulatory system and the earnings management practices. Third, to test the robustness of our findings, we apply several gender diversity measures not yet widely used in the literature. Fourth, we follow a methodological strategy based on the application of several alternative panel data methodologies. These econometric methods allowed us to control for the unobservable heterogeneity problem and the simultaneity or endogeneity problem.

We found evidence that more female presence on the boards of directors leads to less earnings manipulation practices in European countries. These findings are in line with the existing literature. Additionally, we observe that the existence of laws mandating female quotas for more gender equilibrated boards have a positive effect in constraining the managerial opportunistic behavior. All these results reveal the timeliness of laws and recommendations regarding board gender diversity in the countries analyzed.

The paper proceeds as follows. In addition to this introductory section, the next section summarizes the literature review and develops the research hypotheses. Section 2 describes the methodological strategy used in the empirical analysis. Section 3 discusses the empirical results and finally, in Last Section, we underline the major conclusions.

\section{Literature review and hypotheses}

\subsection{Earnings management and board gender diversity}

Research related to economics and psychology in general finds that women are more risk averse and more cautious than men in their financial decisions (Byrnes et al., 1999; Cohn et al., 1975; Estes \& Hosseini, 1988; Riley Jr. \& Chow, 1992). Barua, Davidson, Rama, and Thiruvadi (2010) and Sexton and Bowman-Upton (1990) examined corporate financial and investment decisions made by female executives compared with male executives and found evidence that men exhibit relative overconfidence in significant corporate decision making compared to women. Similarly, Francis, Hasan, Park, and Wu (2015) studied the positive impact of CFO gender diversity on financial reporting in the context of accounting conservatism.

Empirical evidence also shows that women have more ethical conduct than men at the corporate level in their perception of ethical business dilemmas (Bernardi, 1994; Bernardi \& Arnold, 1997; Betz, O’Connell, \& Shepard, 1989; Fallan, 1999; Ruegger \& King, 1992). These 
gender theories support the intuition that more women in companies' boards of directors improves the quality of reported earnings and the reduction of earnings management.

Previous research on the relationship between board gender diversity and the capacity of managers to manipulate earnings highlights the relevance of women's role in reducing agency conflicts and acting actively as efficient monitors. For instance, Barua et al. (2010) examined the association between the gender of chief financial officers and the quality of accruals. They concluded that companies with female CFOs have lower performance-matched absolute discretionary accruals and lower absolute accrual estimation errors, confirming in this way the constraints imposed by monitoring role of females on managerial opportunistic behavior. In a more contextualized case, as was in the UK, Arun, Almahrog, and Ali Aribi (2015) showed that firms with a higher number of women as independent directors are more prone to adopt restrained earnings management practices. Similarly, from a sample of firms from the Fortune 500 index, Krishnan and Parsons (2008) find that earnings quality is positively associated with gender diversity in senior management; and in the same vein, Srinidhi, Gul, and Tsui (2011) find that greater female participation on their boards exhibited higher earnings quality for a sample of US firms. Additionally, Gavious, Segev, and Yosef (2012) found evidence of a negative relation between the presence of female directors and earnings management. They conclude that the gender of directors has value implications for analysts and investors, suggesting that there is a positive relation between the proportion of female directors and the firm value. These results are supported by the unique characteristics of women with regard to business ethics and risk aversion, as discussed earlier, and findings regarding women's motivation and achievement, moral values, social stereotypes and the relation between task performance and self-confidence (Gul, Fung, \& Jaggi, 2009; Srinidhi et al., 2011).

Concerning the participation of female board members on specific board committees, Thiruvadi and Huang (2011), using a sample of S\&P Small Cap 600, found consistent evidence that the presence of a female director on the audit committee constrains accrual-based earnings management. Female directors are found to have a significant influence on the quality of financial reporting and contribute considerably to the efficacy of corporate governance. Pucheta Martínez, Bel Oms, and Olcina Sempere (2016) found that a higher percentage of female directors on different committees increases the likelihood of further transparency by disclosing audit reports with less uncertainties and scope limitation qualifications. In summary, more diversity in boards of directors contributes to board effectiveness (Huse \& Solberg, 2006), enhanced strategic controls (Nielsen \& Huse, 2010) and corporate social responsibility (Adams \& Ferreira, 2009b), and improvements of earnings forecasts (Chapple, Dunstan, \& Truong, 2018). Hence, all the previous literature suggests the following research hypothesis: H1: More female presence on the board of directors leads to less earnings manipulation.

\subsection{Regulatory environment and board gender diversity}

Legal instruments and voluntary regimes are the two main types of legal tools used by governments to cut the gender gap in the boards of directors of corporations. This section describes the regulatory system concerning board gender diversity among the countries analyzed in this study. 
Differentiating between countries with quota laws and those with quota recommendations, it is possible to say that, on the one hand, Norway was the first European country to include quotas on top corporate boards in 2003 , requiring at least $40.00 \%$ of the members to be on each gender for larger boards. For 2015 Norway reached $46.70 \%$ of women on boards of directors, being the European leader in closing the gender gap. Italy is another country that issued a law mandating gender quota for listed companies and for state-owned enterprises. Under the new regulation at least one-third (one-fifth for the first term) of board seats must be held by directors of the less represented gender. This provision has been in force since August 2012.

On the other side, countries with no quota legislation include Sweden. In January 2017 its parliament rejected plans to introduce legislation that would fine listed companies who fail to appoint women to at least $40.00 \%$ of board seats. The Swedish Code on Corporate Governance valid for listed private and public limited-liability companies includes a rule that an equal distribution among the genders shall be the goal (Numhauser-Henning, 2015).

The policies and legislation implemented in Denmark aim to ensure flexibility for the companies by not making binding obligations (fixed targets for example), and instead prioritizing the principle of self-management by leaving it up to the companies to set their own goals. The new legal framework entered into force on 1 April 2013.

The Good Governance Code of listed companies (CNMV, 2015) in Spain establishes among its principles that director nomination policy should seek a balance of knowledge, experience and gender in the board's membership. Among its recommendations is one that dictates that the director nomination policy should pursue the goal of having at least $30.00 \%$ of total board seats occupied by women directors before the year 2020. Although the 3/2007 Equality law gave Spanish public companies and listed firms eight years, until 2015, to achieve a representation in their boards of a minimum of $40.00 \%$ and a maximum of $60.00 \%$ of each gender, the absence of sanctions for noncompliant companies weakened the effectiveness of the statutory policy (Lombardo, 2015).

In Germany's case, the Berlin Declaration of 2011 required a binding legal regulation of $30.00 \%$ women on advisory boards of listed, co-determined, and public companies (Botsch, 2015). Board-level gender quotas were introduced in 2015 by the Act on Equal Participation of Men and Women in Leadership Positions in the Private and the Public Sector. According to this act, there is a mandatory $30.00 \%$ quota for the underrepresented sex on non-executive boards (Fixed Gender Quota), i.e. supervisory boards or, in one-tiered board structures, administrative boards of listed corporations that are subject to co-determination (i.e. to employee-participation on these boards). The act also establishes women quotas individually determined by each affected company (Individual Women Quotas) for the members on its supervisory board, executive board (depending on the type of company) and the two uppermost levels of the management of corporations that are listed or subject to co-determination (or both). Non-compliance with gender quota requirements is sanctioned by empty board seats or administrative fines (Prat \& Mueller, 2016).

The Act on Equality between women and men in Finland applies only to state-owned companies and requires boards of state-owned companies to have at least $40.00 \%$ of both men and women. The Act 31/2014, which amends the Corporate Enterprises Act for the improvement of corporate governance, recommends gender diversity when appointing board 
members must be ensured, facilitating the incorporation of women into the selection process, but does not discuss quotas or establish sanctions for breaking the law.

Board-level gender quotas were introduced in France by the Act of 27 January 2011 on the Balanced Representation of Women and Men on Governing and Supervisory Boards and on Professional Equality. The act requires that the governing and supervisory boards of companies shall be staffed seeking a balanced representation of women and men. It establishes a mandatory $40.00 \%$ minimum quota of members of each sex on the governing and supervisory boards of companies (mandatory gender quotas). This obligation applies to the boards of private sector listed companies that during three consecutive years employed at least 500 permanent employees, and also having a net turnover or total assets of at least EUR 50 million. The act establishes sanctions for infringing the law (Prat \& Mueller, 2016).

The UK has not adopted a quota system for board of directors. Instead, the governmentcommissioned report published in February $2011^{1}$ by Lord Davies recommended a voluntary, business-led framework in which UK listed companies in the FTSE 100 should be aiming for a minimum of $25.00 \%$ female board member representation by 2015 and FTSE 250 to aim for $25.00 \%$ target in a longer timeframe. The goal was reached for the FTSE 100.

Portugal adopted the Government Resolution of 8 March 2012 obliging state-owned companies to adopt gender equality plans aiming, inter alia, at promoting gender balance in management and executive positions. The government has also recommended that listed companies adopt such plans ${ }^{2}$. Portugal passed law 62/2017, August 1, with the purpose of attaining balanced representation between women and men in the director and supervisory bodies of public sector companies and listed companies. The law requires public and listed companies to have one third of representation by women. This new law, to be enforced on January 1, 2018, will see at least $33.33 \%$ of women representation in public and listed companies in Portugal by 2020. To summarize this information, we present the following explanatory in Table 1.

Table 1 . Gender diversity gap and quotas

\begin{tabular}{|l|c|c|c|c|c|c|}
\hline Country & $\begin{array}{c}\text { Gender gap } \\
\text { index WEF }\end{array}$ & $\begin{array}{c}\text { Quota/No quota for } \\
\text { private companies }\end{array}$ & $\begin{array}{c}\text { Effective } \\
\text { since when }\end{array}$ & Sanctions & Legal Origin & 2017 \\
\hline Norway & 0.830 & Yes-2003 & 2005 & Yes & Civil-law & 44.0 \\
\hline Italy & 0.692 & Yes-2011 & 2012 & Yes & Civil-law & 32.9 \\
\hline Sweden & 0.816 & No & - & - & Civil-law & 35.5 \\
\hline Denmark & 0.776 & No & - & - & Civil-law & 28.0 \\
\hline Spain & 0.746 & Yes-2007 & 2015 & No & Civil-law & 21.5 \\
\hline Germany & 0.778 & Yes & 2016 & Yes & Civil-law & 29.7 \\
\hline Finland & 0.823 & No & - & - & Civil-law & 32.3 \\
\hline Portugal & 0.734 & Yes - 2017 & 2018 & Yes & Civil-law & 15.5 \\
\hline France & 0.778 & Yes-2011 & 2017 & Yes & Civil-law & 42.1 \\
\hline UK & 0.770 & No. Davies report 2011 & - & - & Common-law & 27.7 \\
\hline
\end{tabular}

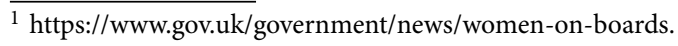

2 http://ec.europa.eu/justice/gender-equality/files/womenonboards/womenonboards-factsheet-pt_en.pdf.
} 
Armstrong, Guay, and Weber (2010) find that legal instruments to enforce quotas are an effective and fast means of achieving change. The use of voluntary regimes has led to some increases in the proportion of women on corporate boards, but the effects are significantly smaller and slower, as is the case of Spain. For instance, Gregorič, Oxelheim, Randøy, and Thomsen (2017) demonstrate that the degree of legal coercion behind the institutional pressure for female directorship is positively associated with the share of women on the board of directors of firms in Denmark, Finland, Sweden, and Norway. They suggest that before the absence of quota laws, as the organizational adaptation to societal expectations for more female directors, it should be supplemented by additional policies to ensure the transparency of board changes.

Hence, it is expected that the legislation and its enforcement concerning companies' board gender diversity is aimed at having more efficient and shareholder-focused boards. Thus, performance enhanced boards through statutory gender diversity should result in better monitoring that constraints the management of accounting earnings. For instance, Arun et al. (2015) and Gavious et al. (2012) provide evidence that statutory diversity plays an active role in ensuring the quality of reported earnings. In this research, we use a female board member quota as a statutory measure of gender diversity, suggesting the following hypothesis:

H2: Less earnings manipulation is expected in countries with quota systems.

\section{Methodology design}

\subsection{Sample}

The goal of this study is to analyze the impact of board gender diversity on discretionary accruals as a measure of earnings manipulation, and the moderating effect of statutory female board member quotas. The statistical analysis was conducted with a sample of European companies listed in their respective market indexes. Hence, the sample included annual financial data of companies from Denmark (KFX index), Finland (HEX 25 index), France (CAC index), Germany (DAX index), Italy (IT 30 index), Norway (OBX index), Portugal (PSI 20 index), Spain (IBEX 35 index), Sweden (SE30 index), and United Kingdom (UKX index). The data set comprises financial, market, and ownership structure information for the period from 2006 to 2016 obtained from Thomson Reuters Eikon. The contextual variables were taken from the publicly available information at the country level published by the World Bank and the Heritage Foundation. Specifically, we used the government effectiveness index which is one of the composite categories included in the World Governance Indicator according to Kaufmann, Kraay, and Mastruzzi (2011), and the Economic Freedom Index of the Heritage Foundation. As usual in empirical analyses, in order to minimize the biases in the final results, we omitted all companies in technical bankruptcy (with negative total common equity), those with missing relevant information for the construction of variables, and those within the financial and banking industry since their specific regulation and financial reporting system does not exhibit many of the needed variables for the empirical analysis. Hence, the panel data includes a total of 1,269 firm-year observations, with an average of 6.6 
observations per company as described in Table $1^{3}$. The sample of firms used in the analysis is representative of the companies in their respective markets. As observed, our sample represents an average of $56.30 \%$ of the constituents of the market indexes of the countries considered in the analysis ${ }^{4}$.

\subsection{Methodology}

The econometric strategy is based upon panel data estimations. When using panel data regressions, we face the econometric limitations of the unobservable heterogeneity problem (Gormley \& Matsa, 2014) and the simultaneity or endogeneity problem (Baltagi, 2013; Roberts \& Whited, 2013; Wintoki, Linck, \& Netter, 2012). The first problem refers to the specific, time-invariant characteristics of each firm (e.g. firm culture, business strategy, internal policies etc.); whilst the endogeneity problem arises due to the imprecision of the direction of the causality between some independent variables and dependent variable. For instance, the corporate governance features of board diversity impact the earnings management, but at the same time, earnings manipulation may also impact the board gender diversity. Therefore, since in this study both gender diversity and the other board features are endogenously determined (Gull, Nekhili, Nagati, \& Chtioui, 2017), we use a carefully formulated methodology to deal with firm-level differences and endogeneity issues.

The first regression method corresponds to the panel data with fixed effect (FE) specifications to tackle the unobservable heterogeneity problem. Hausman (1978) contrast allows us to compare the fixed and the random effects under the null hypothesis that the individual effects are uncorrelated with the other regressors in the model specifications. As exhibited in all the regressions in Table 5, the Hausman test rejects random effects and allows us to accept the existence of time-invariant effects. In addition to the Hausman test, the Breush-Pagan contrast is used to check whether the estimated variance of the residuals is dependent on the values of the independent variables (e.g. heteroskedasticity). As a preliminary estimation we found that the Breush-Pagan test rejected the absence of firm specific effect, which means that the ordinary least squared (OLS) estimations are inconsistent, and consequently, FE estimations are more suitable. As a post estimation of the FE, we followed Greene (2003) and calculated a modified Wald statistic for groupwise heteroskedasticity in the residuals of each fixed effect regression. Additionally, the uncentered variance inflation factor test (VIF) is used to determine the inexistence of autocorrelation problems in the estimations. As observed in the regressions reported in all tables, the values of VIF do not exceed 2.5 which are often regarded as indicating multicollinearity.

Given that in a minor number of estimations, the null hypothesis of homoskedasticitydistributed as a Chi-squared-was rejected in the fixed effect estimations, we proceeded with the Feasible Generalized Least Squared estimations (F-GLS) and the panel-corrected stan-

\footnotetext{
${ }^{3}$ It is a sine qua non condition when using panel data to observe at least four consecutive years of cross-sections (Arellano \& Bond, 1991).

${ }^{4}$ As one might expect, such average is substantially higher if adjusted by excluding from the calculation the financial companies that are part of the market indexes.
} 
dard error (PCSE). ${ }^{5}$ These strategies allow estimation in the presence of first-order autocorrelation within panels and cross-sectional correlation and heteroskedasticity across panels. ${ }^{6}$

Finally, the panel-data GMM Two-Step System Estimator (GMM-SE) is used to properly control for the endogeneity problems and individual heterogeneity of companies included in our sample (Blundell \& Bond, 1998). This methodology uses adjusted standard errors for potential heteroskedasticity as a superior estimation method (Blundell \& Bond, 1998) in comparison with the Dynamic GMM and requires the proper choice of instrument for those variables that are presumably endogenous (Alonso-Borrego \& Arellano, 1999). Therefore, the choice of instruments is a key decision in handling the endogeneity problem (Bond, 2002). According to Arellano (2003), Hsiao (2007), and Baltagi (2013), the advantages that panel data have over time series data or cross-section data refer to greater degrees of freedom, less multicollinearity, and more variation in the data, ultimately resulting in more efficient estimators.

\subsection{Variables measurement}

\subsubsection{Dependent variable}

The dependent variable corresponds to the earnings management. Given that this critical variable is not perfectly observable, we must use proxy variables, and in doing so we applied three alternative methods used in the empirical literature. All the accrual-based measures of earning management are based upon the magnitude of accruals which proxies the extent to which managers exercise discretion in reporting earnings (Dechow, 1994).

We follow Leuz, Nanda, and Wysocki (2003) and Kyaw, Olugbode, and Petracci (2015) for our first measure of earning management (EM1), calculated as the operating accruals as:

$$
E M 1=\left|\frac{A C C_{i t}^{M 1}}{O C F_{i t}}\right|,
$$

where $A C C_{i t}^{M 1}$ is the total accruals in model 1 calculated as $A C C_{i t}^{M 1}=\left(\Delta C A_{i t}-\Delta C a s h_{i t}\right)-$ $\left(\Delta C L_{i t}-\Delta S T D_{i t}-\Delta T P_{i t}\right)-D A_{i t}$ for the firm $i$ in the period $t$. Knowing that $\Delta C A_{i t}$ is the annual change in total current assets, $\Delta C a h_{i t}$ is the change in cash and equivalent, $\Delta C L_{i t}$ is calculated as the change in total current liabilities, $\triangle S T D_{i t}$ is the change in short-term debt included in current liabilities, $\Delta T P_{i t}$ is the change in income taxes payable and $\Delta D A_{i t}$ is the change in depreciation and amortization expenses. The numerator in Equation (1) is scaled by $O C F_{i t}$ which corresponds to the cash flows from operations to control for differences in firm size and performance.

\footnotetext{
${ }^{5}$ For space saving reasons the F-GLS and the PCSE estimations are not reported, but they are available upon request to the corresponding author.

${ }^{6}$ In their well-cited paper, Beck and Katz (1995) demonstrated that Feasible Generalized Least Square specifications produce coefficient standard errors that are severely underestimated. Furthermore, by using Monte Carlo experiments, they report that PCSE estimator produces accurate standard error estimates at no or little loss in efficiency compared to F-GLS. However, in a more recent research, Reed and Webb (2010) claim that when the explanatory variables are characterized by substantial persistence -which is not necessarily for our case-, the PCSE estimator falls short in comparison to F-GLS. Hence, to minimize the bias in the parameters estimates because of the chosen methodology, the F-GLS and PCSE are simultaneously used as robustness checks of our major findings.
} 
Our second measure of earnings manipulation corresponds to a cross-sectional model of discretionary accruals based on Dechow, Sloan, and Sweeney (1995). To get the discretionary accruals, the total accruals in model $2\left(A C C_{i t}^{M 2}\right)$ are estimated as $A C C_{i t}^{M 2}=\left(\triangle C A_{i t}\right.$ $\Delta$ Cash $\left._{i t}\right)-\left(\Delta C L_{i t}-\Delta S T D_{i t}\right)-D A_{i t}$. Where all the inputs are the same as those already defined above.

Once the total accruals are calculated, they are split into their non-discretionary and discretionary components. Non-discretionary accruals are aimed to improve the informational content of financial statements. According to Jones (1991) model, total accruals are affected by the firm's usual business (which can affect non-cash current assets and liabilities) and by fixed assets (which can affect the depreciation expense). Consequently, $A C C_{i t}^{M 2}$ are regressed depending on the change in sales $\left(\Delta\right.$ Sales $\left._{i t}\right)$ and the gross level of property, plant, and equipment $\left(P P E_{i t}\right)$ in the following equation, where variables are scaled by one-period lagged total assets $\left(A_{i t-1}\right)$ :

$$
\frac{A C C_{i t}^{M 2}}{A_{i t-1}}=\beta_{0}+\beta_{1} \frac{\Delta \text { Sales }_{i t}}{A_{i t-1}}+\beta_{2} \frac{P P E_{i t}}{A_{i t-1}}+\varepsilon_{i t} .
$$

Regarding the expected signs for $\beta_{1}$ and $\beta_{2}$ it might be said that this is not trivial, except for $\beta_{2}$. In this case, it is expected that $\beta_{2}$ be negative because depreciation has been included with a negative sign in the definition of total accruals $\left(A C C_{i t}^{M 2}\right)$. However, there is not a clear prediction for the sign of $\beta_{1}$ because, on the one hand, higher level of sales might imply higher accounts receivable but, on the other hand, increases in sales usually imply increases in short-term debt too, so the net effect on the working capital might not be determined $a$ priori.

Hence, the value of $A C C_{i t}^{M 2}$ is the level of total accruals based on the firm's activity and the composition of the firm's assets. Therefore, the error term $\left(\varepsilon_{i t}\right)$ in that regression, which is the difference between observed and estimated accruals as stated in Equation (2), would become the part of total accruals due to the discretionary behavior of managers (EM2).

Given that the discretionary behavior in earnings management might be used either to increase or reduce the earnings, we follow Gabrielsen, Gramlich, and Plenborg (2002) and calculate the absolute value of the second proxy of earnings management (EM2) to measure the extent of the discretionary behavior rather than its direction.

The third measure used of earnings management (EM3) is also a cross-sectional model based on discretionary accruals according to Jones (1991)'s model. In this case, the total accruals $\left(A C C_{i t}^{M 3}\right)$ are estimated as:

$$
\frac{A C C_{i t}^{M 3}}{A_{i t-1}}=\beta_{0}+\beta_{1} \frac{\Delta \text { Sales }_{i t}-\Delta A R_{i t}}{A_{i t-1}}+\beta_{2} \frac{P P E_{i t}}{A_{i t-1}}+\mu_{i t},
$$

where all the variables are those already described before and $\triangle A R$ is the annual change in accounts receivable. Following Cohen, Dey, and Lys (2008), while computing the nondiscretional accruals, we adjust the reported revenues on the sample of firms for the change in accounts receivable to capture any potential accounting discretion arising from sale credits. Similarly as before, the measure of discretionary accruals as our third proxy of earnings manipulation (EM3) is computed as the difference between total accruals and the fitted non-discretionary accruals defined corresponding to the residuals $\left(\mu_{i t}\right)$ in Equation (3). 


\subsubsection{Independent variables}

Gender diversity, the most important independent variable in this study, is estimated in different ways. Typically, we define it as the percentage of women on the board (GD1) which basically represents the share of female members to the total number of board members. Nevertheless, given that a board composed only by male members or female members is characterized by lack of diversity, we follow Martín-Ugedo and Minguez-Vera (2014) and Abad, Lucas-Pérez, Minguez-Vera, and Yagüe (2017) and use two additional indexed measures of gender diversity that take into account the proportion of both gender categories. These indexed measures correspond to the Blau (1977) Index (GD2) and the Shannon (1948) Index $(G D 3)$ of diversification. Blau Index is computed as $G D 2=1-\sum_{i=1}^{n} P_{i}^{2}$, where $P_{i}$ corresponds to the proportion of directors in each $n=2$ gender categories (male and female members). The range of values of GD2 variable is between 0 , when there is no gender diversity at all, meaning that there are only male members or female members on the board, and 0.5 when there is an equal proportion of male and female members on the board. The Shannon Index is calculated with the same inputs as Blau Index as $G D 3=\left|\sum_{i=1}^{n} \operatorname{Ln} P_{i}^{P_{i}}\right|$. GD3 variable takes values between 0 , when there is no gender diversification and 0.693 when there is an equal proportion of each gender category. This index assumes that GD3 $=0$ when $P_{i}=0$. G2 and GD3 variables are highly correlated as observed in Table 4, but GD3 is more sensitive to small changes in gender diversity that GD2 due to its logarithmic transformation (Abad et al., 2017) - as observed when comparing their standard deviations shown in Table 3. Hence, we look at these measures as complementary measures of board gender diversity rather than substitute indicators, and due to that, both are used in our estimations.

In addition to these variables of gender diversity, we also considered a dummy covariate to measure the impact of quota systems $\left(Q S_{i t}\right)$ across countries on earnings management to test our second research hypothesis. Hence, $Q S_{i t}$ takes value 1 if the country in a certain year had a required quota system as a minimum number of female board members and zero if no quota is required.

As control variables we included similar information as in previous empirical papers. For instance, we entered the board size $\left(B_{S i z e}{ }_{i t}\right)$ which is measured as the natural logarithmic transformation of the total number of board members. The number of independent board members $\left(B I n d e p_{i t}\right)$ as a share of the total number of board members is used to represent the extent to which the board decisions are not influenced by insiders' interest. The proportion of shares in hand of the majority shareholder $\left(O w n_{i t}\right)$ is used as a governance variable to measure the agency problem caused by the separation between ownership and the firm's control. Firm size $\left(\right.$ Size $\left._{i t}\right)$ is also used as a control variable that corresponds to the logarithmic transformation of the firm's total assets reported. A leverage measure $\left(\right.$ Lev $\left._{i t}\right)$ calculated as the total liabilities over total assets is also used. Two market measures are included in the empirical analysis. The widely known proxy of Tobin's $\mathrm{Q}$ for growth opportunities $\left(T Q_{i t}\right)$ is implemented on the one hand, and the market-to-book ratio $\left(M T B_{i t}\right)$ on the other hand. $T Q_{i t}$ is computed as the equity market value plus debt at book value, and then everything is scaled 
by the addition of common equity and debt at book value. $M T B_{i t}$ variable is calculated as the market capitalization over the total common equity. Another firm-specific characteristic used in the empirical analysis is the Altman (1968)'s Z-score $\left(Z_{i t}\right)$ as a measure of the firm's default risk, calculated as $Z_{i t}=\frac{\left(1.2 W K_{i t}+1.4 R E_{i t}+3.3 E B I T_{i t}+0.99 \text { Sales }_{i t}\right)}{A_{i t}}+\frac{0.6 M K_{i t}}{T L_{i t}}$, where $W K_{i t}$ is the working capital, $R E_{i t}$ represents the retained earnings, $E B I T_{i t}$ is the earnings before interest and taxes or net operating income, Sales ${ }_{i t}$ are the total revenues, $M K_{i t}$ is the market capitalization calculated as the number of shares outstanding multiplied by the yearend share price, and $A_{i t}$ and $T L_{i t}$ are the firm's total assets and the total liabilities, respectively. The return on assets $\left(R O A_{i t}\right)$ entered the analysis as the net income scaled by total assets.

In addition to this set of firm-level variables, we also controlled for contextual or countrylevel governance effectiveness variables. We think that there is a cross country heterogeneity that might impact the extent of the earnings management. Particularly, we used the Worldwide Government Effectiveness Index $\left(W G E_{t c}\right)$ which changes over time $t$ and country $c$. This index is an aggregate indicator that incorporates the following six governance characteristics according to Kaufmann et al. (2011): voice and accountability, political stability and absence of violence/terrorism, government effectiveness, regulatory quality, rule of law, and the control of corruption. This indicator ranges from -2.5 and 2.5 and takes greater values as the government at country level improves. Additionally, we used the Index of Economic Freedom $\left(I E F_{t c}\right)$ as another contextual variable. This measure of economic freedom is based upon twelve quantitative and qualitative factors, grouped into the following four broad categories of economic freedom: rule of law, government size, regulatory efficiency, and open markets. Each of these categories is graded on a scale of 0 to 100, and a country's overall index is derived by averaging the scores. The greater the index, the better the economic freedom and consequently its underlying categories ${ }^{7}$. Finally, time and country dummy variables were used to control for temporal and cross-country fixed effects.

Consequently, based on our hypotheses, we have formulated our multicounty-baseline empirical specification that takes the following form:

$$
E M_{i t c}=\beta_{0}+\beta_{1} G D_{i t c}+\sum_{j=1}^{J} \gamma_{j} F L V_{i t c}+\sum_{k=1}^{K} \delta_{k} C L V_{i t c}+\eta_{i}+\mu_{t}+\varepsilon_{i t},
$$

where EM represents our alternative measures of discretionary accruals as proxies for earnings management, GD summarizes the various measures of gender diversity in the board of directors, $F L V$ is the vector of $J=9$ control, firm-level variables corresponding to the board size $\left(B S i z e_{i t c}\right)$, board independency $\left(B I n d e p_{i t c}\right)$, firms' ownership structure $\left(O w n_{i t c}\right)$, company size $\left(\right.$ Size $\left._{i t c}\right)$, leverage $\left(\operatorname{Lev}_{i t c}\right)$, growth opportunities $\left(T Q_{i t c}\right)$, market-to-book ratio $\left(M T B_{i t c}\right)$, firms' default risk $\left(Z_{i t c}\right)$, and profitability $\left(R O A_{i t c}\right)$. CLV is a vector which includes the $K=4$ contextual or country-level covariates like the Worldwide Government Effectiveness Index $\left(W G E_{t c}\right)$, the Index of Economic Freedom $\left(I E F_{t c}\right)$, and the dummy temporal and country variables. $\eta_{i}$ is the individual, firm-specific time invariant effect, $\mu_{t}$ is the time effect, and $\varepsilon_{i t}$ is the stochastic error term.

\footnotetext{
${ }^{7}$ Visit https://www.heritage.org/index/about for further details about the construction and source of the Index of Economic Freedom.
} 


\section{Results}

\subsection{Univariate analysis}

This section describes the general picture of the variables used in the empirical analysis. Besides the panel composition, Table 2 shows how the three alternative measures of earnings management are exhibited across countries. Portugal, Norway, Germany and Spain are the countries with the highest EM1 variable. Conversely, with the lowest measure of earnings management (EM1) we find Sweden and Denmark. However, regarding EM2 and EM3, we observe that Portugal again is the country with the highest manipulation of financial statements.

Table 2. Panel composition

\begin{tabular}{|l|c|c|c|c|c|c|c|c|c|}
\hline \multirow{2}{*}{ Country } & \multirow{2}{*}{ EM1 } & \multirow{2}{*}{ EM2 } & \multirow{2}{*}{ EM3 } & \multirow{2}{*}{$\begin{array}{c}\text { \% on } \\
\text { Index }\end{array}$} & \multicolumn{2}{|c|}{ Observations } & \multicolumn{2}{|c|}{ Companies } & \multirow{2}{*}{$\begin{array}{l}\text { Average Obs. } \\
\text { per Company }\end{array}$} \\
\cline { 6 - 9 } & & & & & $\mathrm{N}$ & $(\%)$ & $\mathrm{N}$ & $(\%)$ & \\
\hline DIN & 0.509 & 0.043 & 0.034 & 75.00 & 78 & 6.15 & 15 & 7.81 & 5.2 \\
\hline ESP & 0.963 & 0.038 & 0.034 & 65.71 & 179 & 14.11 & 23 & 11.98 & 7.8 \\
\hline FIN & 0.711 & 0.037 & 0.037 & 84.00 & 148 & 11.66 & 21 & 10.94 & 7.0 \\
\hline FR & 0.569 & 0.026 & 0.028 & 50.00 & 124 & 9.77 & 20 & 10.42 & 6.2 \\
\hline GER & 1.002 & 0.037 & 0.031 & 53.33 & 112 & 8.83 & 16 & 8.33 & 7.0 \\
\hline ITA & 0.766 & 0.042 & 0.038 & 40.00 & 107 & 8.43 & 12 & 6.25 & 8.9 \\
\hline NOR & 1.049 & 0.051 & 0.041 & 48.00 & 73 & 5.75 & 12 & 6.25 & 6.1 \\
\hline PORT & 1.089 & 0.046 & 0.046 & 40.00 & 59 & 4.65 & 8 & 4.17 & 7.4 \\
\hline SWEDEN & 0.425 & 0.034 & 0.033 & 60.00 & 91 & 7.17 & 18 & 9.38 & 5.1 \\
\hline UK & 0.691 & 0.035 & 0.030 & 47.00 & 298 & 23.48 & 47 & 24.48 & 6.3 \\
\hline Total & 0.760 & 0.037 & 0.033 & 56.30 & 1,269 & 100.00 & 192 & 100.00 & 6.6 \\
\hline
\end{tabular}

We use Table 3 to show basic descriptive statistics of all the variables used in the analysis. First, we test the hypothesis that the mean values of the three alternative measures of earnings management are equal to zero. As observed in Table 3, we reject such null hypothesis at the highest confidence level and consequently accept the fact that their mean values are different from zero. This preliminary result is shown as evidence that managers in our sample of companies discretionarily manipulate their results, either by increasing profits or reducing them. This finding is in line with Saona and Muro (2017) and García and Gill-de-Albornoz (2007) for the Latin American and Spanish contexts, respectively.

Concerning the female representation in the board of directors of companies (GD1), we observe that on average only 2 out of 10 board members are women, with a maximum representation of less than 6 of every 10 board members. Regarding the two other alternative measures of gender diversity, we confirm that the board structures are way below what is considered a balanced or equal representation of both genders. For instance, GD2 and GD3 have average values of only 0.291 and 0.443 , respectively; which are substantially lower than what is considered balanced representation of women and men, corresponding to indexes of 0.50 and 0.693 , respectively. We observe that in the sample about $16.60 \%$ of the observations correspond to firms where quota systems are required by law. 
Table 3. Descriptive statistics

\begin{tabular}{|l|c|c|c|c|}
\hline \multicolumn{1}{|c|}{ Variable } & Mean & Std. Dev. & Min & Max \\
\hline EM1 & $0.760^{* * *}$ & 1.256 & 0.017 & 7.378 \\
\hline EM2 & $0.037^{* * *}$ & 0.040 & $>0.000$ & 0.241 \\
\hline EM3 & $0.033^{* * *}$ & 0.069 & $>0.000$ & 0.282 \\
\hline GD1 & 0.203 & 0.130 & 0.000 & 0.571 \\
\hline GD2 & 0.291 & 0.153 & 0.000 & 0.500 \\
\hline GD3 & 0.443 & 0.209 & 0.000 & 0.693 \\
\hline QS & 0.166 & 0.371 & 0.000 & 1.000 \\
\hline Bsize & 2.422 & 0.314 & 1.386 & 3.219 \\
\hline Bindep & 0.529 & 0.248 & 0.000 & 1.000 \\
\hline Own & 0.187 & 0.172 & 0.012 & 1.000 \\
\hline Size & 23.134 & 1.360 & 19.154 & 27.220 \\
\hline TQ & 1.664 & 1.100 & 0.547 & 19.927 \\
\hline MTB & 3.112 & 3.253 & 0.065 & 22.207 \\
\hline Lev & 0.655 & 0.162 & 0.022 & 0.995 \\
\hline$Z$ & 2.889 & 1.993 & 0.552 & 14.662 \\
\hline ROA & 0.048 & 0.067 & -0.395 & 0.334 \\
\hline IEF & 4.260 & 0.077 & 4.074 & 4.381 \\
\hline GE & 1.503 & 0.462 & 0.198 & 2.354 \\
\hline
\end{tabular}

The average number of board members is about 11.26 (exponent calculation of the BSize measure of board size) with only $52.90 \%$ being independent members. The ownership structure shows that the majority shareholders hold almost an average of $19.00 \%$ of the outstanding shares. A typical company has an average of $65.50 \%$ of its total assets financed with debt (Lev) with an average return $(R O A)$ of $4.80 \%$ on total assets.

Regarding the two contextual variables used in this study, we observe that the average economic freedom index is around 70 (exponent calculation of the IEF variable), knowing that this variable goes from 0 to 100 with higher values as economic freedom increases. The second country-level variable used is a measure of government effectiveness $(G E)$ which had an average of 1.50, ranging from -2.50 to 2.50 and with higher values showing better governance levels.

In Table 4 we observe that there are not substantially high correlations among the independent variables except for those that measure the same concept, such as the proxies for the discretionary earnings management, gender diversity, and growth opportunities.

\subsection{Multivariate analysis}

\subsubsection{The impact of gender diversity on earnings management}

As mentioned above, several panel-data estimation methods are used to check the robustness of our findings. Tables 5 and 6 display the results of Equation 4 by using individual fixedeffect estimations (FE) and the generalized method of moment (GMM-SE) with the system 


\begin{tabular}{|c|c|c|c|c|c|c|c|c|c|c|c|c|c|c|c|c|c|c|c|}
\hline$\stackrel{0}{-1}$ & & & & & & & & & & & & & & & & & & نே. & 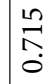 \\
\hline$\stackrel{\Omega}{2}$ & & & & & & & & & & & & & & & & & \& & 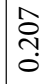 & $\begin{array}{l}0 \\
0 \\
0\end{array}$ \\
\hline$\Xi$ & & & & & & & & & & & & & & & & ¿ִ & $\mid \begin{array}{l}0 \\
\text { in? } \\
0\end{array}$ & 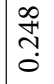 & 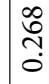 \\
\hline$\stackrel{m}{\longrightarrow}$ & & & & & & & & & & & & & & & $\underset{\text { ¿ }}{8}$ & $\begin{array}{l}\text { N } \\
\text { in } \\
0 \\
1\end{array}$ & \begin{tabular}{l}
0 \\
\multirow{n}{n}{} \\
0 \\
1
\end{tabular} & $\begin{array}{l}0 \\
-0 \\
0 \\
1\end{array}$ & 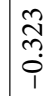 \\
\hline$\simeq$ & & & & & & & & & & & & & & ¿ & $\begin{array}{l}\infty \\
\infty \\
\\
0\end{array}$ & 吕 & 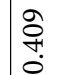 & $\stackrel{\vec{n}}{\stackrel{n}{0}}$ & 范 \\
\hline$\exists$ & & & & & & & & & & & & & ஓ & $\begin{array}{l}\infty \\
\infty \\
0 \\
0 \\
0\end{array}$ & 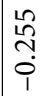 & $\begin{array}{l}\infty \\
0 \\
0 \\
0\end{array}$ & $\begin{array}{l}0 \\
\infty \\
1 \\
0 \\
0\end{array}$ & ஸ̂त & \begin{tabular}{l}
8 \\
0 \\
\hdashline \\
0
\end{tabular} \\
\hline 으 & & & & & & & & & & & & 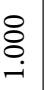 & 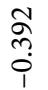 & $\begin{array}{l}0 \\
\infty \\
1 \\
0 \\
1\end{array}$ & $\stackrel{\leftrightarrow}{\tilde{m}}$ & 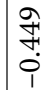 & $\begin{array}{l}0 \\
\\
\\
1\end{array}$ & 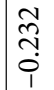 & $\begin{array}{l}\sim \\
n \\
0 \\
1\end{array}$ \\
\hline$a$ & & & & & & & & & & $£$ & & 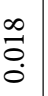 & $\begin{array}{l}\text { oे } \\
\text { ○े } \\
0\end{array}$ & $\begin{array}{l}m \\
0 \\
0 \\
0 \\
1\end{array}$ & $\begin{array}{l}\stackrel{1}{\infty} \\
0 \\
0 \\
0\end{array}$ & $\begin{array}{l}\bar{a} \\
0 \\
\dot{0}\end{array}$ & $\begin{array}{l}0 \\
0 \\
0 \\
0 \\
1\end{array}$ & \begin{tabular}{l}
\multirow{H}{*}{} \\
m. \\
i \\
1
\end{tabular} & 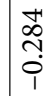 \\
\hline$\infty$ & & & & & & & & & $\stackrel{8}{\circ}$ & $\begin{array}{l}\stackrel{g}{c} \\
\tilde{c} \\
\end{array}$ & & $\begin{array}{c}\infty \\
0 \\
0 \\
0 \\
0 \\
1\end{array}$ & $\begin{array}{l}10 \\
0 \\
0 \\
0\end{array}$ & 告 & $\frac{\vec{\sigma}}{\stackrel{0}{0}}$ & $\exists$ & 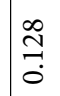 & 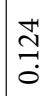 & $\stackrel{ }{\stackrel{\sigma}{\circ}}$ \\
\hline$\wedge$ & & & & & & & & $\stackrel{8}{\circ}$ & $\begin{array}{l}20 \\
7 \\
\\
0\end{array}$ & g & & $\begin{array}{l}\stackrel{8}{0} \\
\text { nె. } \\
0\end{array}$ & 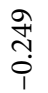 & 啇 & ஸे & 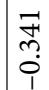 & 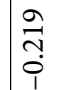 & \begin{tabular}{l}
0 \\
\multirow{1}{*}{} \\
$n$ \\
0 \\
1
\end{tabular} & 홈 \\
\hline 6 & & & & & & & ஓ & $\begin{array}{l}\bar{g} \\
\dot{0} \\
\dot{1}\end{array}$ & $\frac{\circ}{\circ}$ & $\frac{J}{z}$ & & $\begin{array}{l}\stackrel{H}{J} \\
0 \\
\dot{0}\end{array}$ & gे & $\begin{array}{l}0 \\
0 \\
0 \\
0\end{array}$ & $\frac{2}{\stackrel{\sigma}{0}}$ & $\stackrel{n}{\stackrel{n}{0}}$ & $\begin{array}{l}\infty \\
\stackrel{0}{0} \\
0 \\
0\end{array}$ & $\stackrel{H}{\stackrel{H}{0}}$ & $\underset{\tilde{n}}{\tilde{n}}$ \\
\hline in & & & & & & : & & $\begin{array}{l}\stackrel{\circ}{\exists} \\
\stackrel{0}{0}\end{array}$ & $\frac{5}{0}$ & ஓ & & ק̋ & $\begin{array}{l}2 \\
\text { Oे } \\
0\end{array}$ & 苞 & ڤొ & 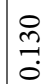 & N̂ & $\stackrel{m}{=}$ & $\begin{array}{l}2 \\
\tilde{n} \\
0\end{array}$ \\
\hline 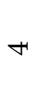 & & & & & ¿ْ & $\begin{array}{l}\stackrel{0}{\alpha} \\
\hat{\sigma}\end{array}$ & $\stackrel{\infty}{\tilde{\sigma}}$ & $\stackrel{2}{\stackrel{1}{0}}$ & $\frac{8}{\circ}$ & 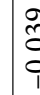 & & $\begin{array}{l}\hat{n} \\
0 \\
\dot{0}\end{array}$ & 옹 & 年 & $\frac{\vec{a}}{\dot{0}}$ & 范 & $\begin{array}{l}\circ \\
\text { ஜn } \\
0 \\
0\end{array}$ & $\begin{array}{l}\infty \\
0 \\
0 \\
0 \\
0 \\
0\end{array}$ & ֶิ \\
\hline$m$ & & & $\S$ & & 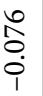 & $\begin{array}{l}8 \\
\stackrel{-}{0} \\
\\
1\end{array}$ & $\begin{array}{l}\stackrel{2}{O} \\
\stackrel{1}{0} \\
1\end{array}$ & $\begin{array}{l}\hat{N} \\
0 \\
0 \\
i\end{array}$ & $\begin{array}{l}2 \\
\stackrel{2}{0} \\
0 \\
0\end{array}$ & $\bar{c}$ & & $\begin{array}{l}\infty \\
\infty \\
\\
\\
1\end{array}$ & مै & F & 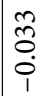 & 守 & $\begin{array}{l}\hat{8} \\
0 \\
0 \\
1\end{array}$ & $\stackrel{n}{8}$ & 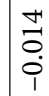 \\
\hline$N$ & & 용 & হ & & $\begin{array}{l}\hat{\hat{O}} \\
\text { Oे } \\
\text { i }\end{array}$ & $\begin{array}{c}\tilde{O} \\
0 \\
\stackrel{0}{0} \\
1\end{array}$ & $\begin{array}{l}\hat{O} \\
\stackrel{0}{0} \\
\end{array}$ & \begin{tabular}{l}
0 \\
\multirow{0}{0}{} \\
0 \\
1
\end{tabular} & $\begin{array}{l}\hat{n} \\
\text { !n } \\
0 \\
0\end{array}$ & $\frac{n}{c}$ & & $\begin{array}{l}\vec{\infty} \\
\overrightarrow{0} \\
\\
\end{array}$ & $\stackrel{\infty}{\infty}$ & F & $\begin{array}{l}\text { n̂. } \\
\stackrel{0}{0} \\
\dot{1}\end{array}$ & f & 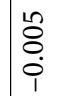 & 范 & $\begin{array}{l}n \\
0 \\
0 \\
0 \\
1\end{array}$ \\
\hline- & ¿̊ & L & $\frac{n}{7}$ & & $\begin{array}{l}\stackrel{\infty}{\mathbb{N}} \\
\stackrel{+}{i}\end{array}$ & $\begin{array}{l}m \\
\stackrel{m}{0}\end{array}$ & $\stackrel{\tilde{n}}{\because}$ & $\begin{array}{l}n \\
\stackrel{n}{0} \\
0\end{array}$ & $\begin{array}{l}\bar{a} \\
0 \\
0 \\
1\end{array}$ & $\frac{5}{c}$ & & 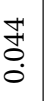 & 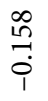 & đa & $\stackrel{ }{\stackrel{2}{\circ}}$ & $\begin{array}{l}\overrightarrow{0} \\
-1 \\
\dot{1}\end{array}$ & 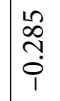 & \begin{tabular}{l}
0 \\
\multirow{O}{0}{} \\
$\stackrel{0}{0}$ \\
$i$
\end{tabular} & $\begin{array}{l}n \\
\tilde{n} \\
0 \\
0 \\
1\end{array}$ \\
\hline$\frac{\stackrel{\mathscr{d}}{0}}{\frac{\pi}{3}}$ & $\underset{|x| y}{F}$ & $\sum_{i=1}^{\mathcal{I}}$ & $\sum_{i=1}^{\infty}$ & & હิ & ิิ & ิિ & बू. & 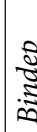 & 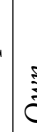 & & $\stackrel{\widetilde{N}}{\sim}$ & $\underset{V}{O}$ & $\stackrel{n}{\xi}$ & دे & $N$ & $\underset{\approx}{\mathbb{Z}}$ & 䞏 & 心 \\
\hline & - & $\sim$ & $n$ & & $r$ & in & 6 & $\wedge$ & $\infty$ & $\circ$ & & 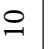 & $\exists$ & $\simeq$ & $\stackrel{n}{2}$ & $\Xi$ & 10 & 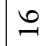 & $\triangle$ \\
\hline
\end{tabular}


estimator, respectively. Estimations with feasible generalized least square (F-GLS) and panel corrected standard error (PCSE) are not reported for saving space reasons, but they are available upon request from the corresponding author.

In all these tables, the beneficial effect of the presence of women on the boards of directors $(G D 1)$ as a proxy of gender diversity on the earnings management practices of companies appears to be robust across all the specifications. In the same way, our results are consistent and statistically significant by using the three different proxies of earnings management (EM1, EM2, and EM3).

Specifically, Table 5 shows the results of the baseline model using the individual timeinvariant effect (FE), in addition to the temporal and country fixed effect. Time fixed-effect accounts for unobservable changes over time, and country fixed effects accounts for unobserved differences per country in the sample. The nine regressions are grouped based on the three alternative dependent variables (EM1, EM2, and EM3). These findings are aligned with our first hypothesis and support the relevance of gender diversity on the board of directors as a mechanism to mitigate corporate earnings management practices. Barua et al. (2010), Srinidhi et al. (2011), Thiruvadi and Huang (2011), for US evidence, found that firms with more women on the board of directors show higher quality earnings. In the same way, Kyaw et al. (2015), for European firms, show that their results highlight the importance of female empowerment.

Table 5 reports the specifications with individual time-invariant effects (FE), which help us to tackle the unobservable heterogeneity problem. As observed at the bottom of the table, the Hausman test rejects the existence of random effects, and consequently, the individual fixed-effect hypothesis is accepted. All the specifications in Table 5 show a negative and statistically significant relationship of the parameter of GD1 with earnings management practices. Estimates in specifications (1) to (3) with an average elasticity of -1.168 , meaning that when women participation on the board changes $10.00 \%$, the associated earnings management amount moves in the opposite direction by $11.70 \%$. It is important to note that the elasticity changes substantially when we consider the other earnings management proxies (see columns 4-9). This negative relationship supports the idea that a higher presence of women on the board of directors constrains earnings management practices in the company. In this respect, there are several arguments that support this negative relationship between the proportion of female board representatives and the earnings management practices. For instance, regarding economic psychology arguments, it has been widely demonstrated that female executives are more risk averse than their male counterparties in their financial decisions (Cohn et al., 1975; Riley Jr. \& Chow, 1992) and more cautious and less aggressive in a variety of other decision contexts (Barua et al., 2010; Huang \& Kisgen, 2013). Concerning the gender of corporate decision makers and accounting conservatism, Francis et al. (2015) observe that, following the hiring of a female executive, there is a significant increase in the degree of accounting conservatism as compared to the degree of their male predecessor. Consequently, the arguments supported by conservatism, caution, less aggressiveness, and risk aversion of female directors strongly support our findings of a negative impact of the proportion of female board members and extent of earnings manipulation. 
Table 5. Women on board and earnings management (OLS-FE regressions)

\begin{tabular}{|c|c|c|c|c|c|c|c|c|c|}
\hline \multirow{2}{*}{ Variables } & (1) & (2) & (3) & (4) & (5) & (6) & (7) & (8) & (9) \\
\hline & \multicolumn{3}{|c|}{ EM1 } & \multicolumn{3}{|c|}{ EM2 } & \multicolumn{3}{|c|}{ EM3 } \\
\hline GD1 & $\begin{array}{c}-1.1853^{\star * *} \\
(-3.1849)\end{array}$ & $\begin{array}{c}-1.1938^{* * *} \\
(-3.0734)\end{array}$ & $\begin{array}{c}-1.1255^{\star * *} \\
(-2.9130)\end{array}$ & \begin{tabular}{|c|}
$-0.0362^{* * *}$ \\
$(-2.7641)$
\end{tabular} & $\begin{array}{l}-0.0235^{\star} \\
(-1.7402)\end{array}$ & $\begin{array}{l}-0.0237^{\star} \\
(-1.7702)\end{array}$ & $\begin{array}{c}-0.0377^{\star * *} \\
(-2.8702)\end{array}$ & $\begin{array}{c}-0.0254^{\star} \\
(-1.8735)\end{array}$ & $\begin{array}{l}-0.0255^{*} \\
(-1.9005)\end{array}$ \\
\hline Bsize & $\begin{array}{c}0.0766 \\
(0.3198)\end{array}$ & $\begin{array}{c}0.0547 \\
(0.2099)\end{array}$ & $\begin{array}{c}0.0381 \\
(0.1462)\end{array}$ & $\begin{array}{c}-0.0065 \\
(-0.7662)\end{array}$ & $\begin{array}{c}-0.0105 \\
(-1.1674)\end{array}$ & $\begin{array}{c}-0.0107 \\
(-1.1818)\end{array}$ & $\begin{array}{c}-0.0079 \\
(-0.9241)\end{array}$ & $\begin{array}{c}-0.0117 \\
(-1.2854)\end{array}$ & $\begin{array}{c}-0.0118 \\
(-1.2978)\end{array}$ \\
\hline Bindep & & $\begin{array}{c}0.2584 \\
(0.9869)\end{array}$ & $\begin{array}{c}0.3114 \\
(1.1959)\end{array}$ & & $\begin{array}{c}0.0001 \\
(0.0113)\end{array}$ & $\begin{array}{c}0.0001 \\
(0.0080)\end{array}$ & & $\begin{array}{c}0.0007 \\
(0.0772)\end{array}$ & $\begin{array}{c}0.0007 \\
(0.0779)\end{array}$ \\
\hline Own & $\begin{array}{c}0.5745 \\
(1.2243)\end{array}$ & $\begin{array}{c}0.6053 \\
(1.2194)\end{array}$ & $\begin{array}{c}0.5502 \\
(1.1084)\end{array}$ & $\begin{array}{c}0.0108 \\
(0.6483)\end{array}$ & $\begin{array}{c}0.0118 \\
(0.6756)\end{array}$ & $\begin{array}{c}0.0116 \\
(0.6686)\end{array}$ & $\begin{array}{c}0.0091 \\
(0.5440)\end{array}$ & $\begin{array}{c}0.0099 \\
(0.5680)\end{array}$ & $\begin{array}{c}0.0098 \\
(0.5592)\end{array}$ \\
\hline Size & $\begin{array}{l}0.1998^{*} \\
(1.7493)\end{array}$ & $\begin{array}{l}0.2520^{* *} \\
(2.0818)\end{array}$ & $\begin{array}{l}0.2826^{\star *} \\
(2.3597)\end{array}$ & $\begin{array}{l}-0.0070^{*} \\
(-1.7416)\end{array}$ & $\begin{array}{l}-0.0079^{*} \\
(-1.8629)\end{array}$ & $\begin{array}{l}-0.0079^{*} \\
(-1.8972)\end{array}$ & $\begin{array}{c}-0.0065 \\
(-1.6070)\end{array}$ & $\begin{array}{c}-0.0073^{\star} \\
(-1.7156)\end{array}$ & $\begin{array}{l}-0.0073^{*} \\
(-1.7445)\end{array}$ \\
\hline TQ & $\begin{array}{c}0.0731 \\
(0.6316)\end{array}$ & & & $\begin{array}{c}0.0066 \\
(1.6282)\end{array}$ & & & $\begin{array}{c}0.0065 \\
(1.5934)\end{array}$ & & \\
\hline$M T B$ & & $\begin{array}{c}0.0218 \\
(0.9741)\end{array}$ & $\begin{array}{c}0.0228 \\
(1.0193)\end{array}$ & & $\begin{array}{c}0.0003 \\
(0.4434)\end{array}$ & $\begin{array}{c}0.0003 \\
(0.4435)\end{array}$ & & $\begin{array}{c}0.0004 \\
(0.4653)\end{array}$ & $\begin{array}{c}0.0004 \\
(0.4658)\end{array}$ \\
\hline Lev & $\begin{array}{c}-0.2034 \\
(-0.3317)\end{array}$ & $\begin{array}{c}-0.3640 \\
(-0.5452)\end{array}$ & $\begin{array}{c}-0.4228 \\
(-0.6331)\end{array}$ & $\begin{array}{c}0.0058 \\
(0.2635)\end{array}$ & $\begin{array}{c}0.0034 \\
(0.1440)\end{array}$ & $\begin{array}{c}0.0032 \\
(0.1336)\end{array}$ & $\begin{array}{c}0.0019 \\
(0.0842)\end{array}$ & $\begin{array}{c}-0.0019 \\
(-0.0780)\end{array}$ & $\begin{array}{c}-0.0021 \\
(-0.0888)\end{array}$ \\
\hline$Z$ & $\begin{array}{c}-0.0112 \\
(-0.1774)\end{array}$ & $\begin{array}{c}-0.0062 \\
(-0.1237)\end{array}$ & $\begin{array}{c}0.0051 \\
(0.1029)\end{array}$ & $\begin{array}{c}-0.0019 \\
(-0.8334)\end{array}$ & $\begin{array}{c}-0.0011 \\
(-0.6214)\end{array}$ & $\begin{array}{c}-0.0010 \\
(-0.5888)\end{array}$ & $\begin{array}{c}-0.0019 \\
(-0.8475)\end{array}$ & $\begin{array}{c}-0.0012 \\
(-0.6678)\end{array}$ & $\begin{array}{c}-0.0011 \\
(-0.6336)\end{array}$ \\
\hline$R O A$ & $\begin{array}{c}-2.7048^{\star * \star} \\
(-4.7425)\end{array}$ & $\begin{array}{c}-2.5408^{\star * *} \\
(-4.3921)\end{array}$ & $\begin{array}{c}-2.5462^{\star * \star} \\
(-4.3971)\end{array}$ & $\begin{array}{c}-0.0106 \\
(-0.4898)\end{array}$ & $\begin{array}{c}-0.0070 \\
(-0.3290)\end{array}$ & $\begin{array}{c}-0.0070 \\
(-0.3278)\end{array}$ & $\begin{array}{c}-0.0073 \\
(-0.3252)\end{array}$ & $\begin{array}{c}-0.0035 \\
(-0.1577)\end{array}$ & $\begin{array}{c}-0.0034 \\
(-0.1541)\end{array}$ \\
\hline$I E F$ & & $\begin{array}{l}-3.2877^{\star} \\
(-1.9128)\end{array}$ & & & $\begin{array}{c}-0.0022 \\
(-0.0357)\end{array}$ & & & $\begin{array}{c}-0.0042 \\
(-0.0676)\end{array}$ & \\
\hline$G E$ & & & $\begin{array}{c}0.3841 \\
(1.2663)\end{array}$ & & & $\begin{array}{c}0.0041 \\
(0.3924)\end{array}$ & & & $\begin{array}{c}0.0041 \\
(0.3930)\end{array}$ \\
\hline Constant & $\begin{array}{c}-3.7545 \\
(-1.4121)\end{array}$ & $\begin{array}{c}9.0725 \\
(1.1007)\end{array}$ & $\begin{array}{l}-6.2012^{* *} \\
(-2.2256)\end{array}$ & $\begin{array}{l}0.2137^{\star *} \\
(2.2796)\end{array}$ & $\begin{array}{c}0.2570 \\
(0.8632)\end{array}$ & $\begin{array}{l}0.2426^{* *} \\
(2.5196)\end{array}$ & $\begin{array}{l}0.2083^{\star *} \\
(2.2145)\end{array}$ & $\begin{array}{c}0.2585 \\
(0.8626)\end{array}$ & $\begin{array}{l}0.2351^{\star *} \\
(2.4337)\end{array}$ \\
\hline Observations & 1,269 & 1,207 & 1,207 & 1,245 & 1,180 & 1,180 & 1,233 & 1,168 & 1,168 \\
\hline $\begin{array}{l}\text { Number of } \\
\text { iden }\end{array}$ & 192 & 190 & 190 & 192 & 191 & 191 & 190 & 189 & 189 \\
\hline Sigma u & 1.111 & 1.163 & 1.123 & 0.0291 & 0.0282 & 0.0285 & 0.0293 & 0.0284 & 0.0287 \\
\hline Sigma e & 0.970 & 0.964 & 0.965 & 0.0343 & 0.0333 & 0.0333 & 0.0343 & 0.0333 & 0.0333 \\
\hline Rho & 0.567 & 0.592 & 0.575 & 0.420 & 0.418 & 0.422 & 0.423 & 0.422 & 0.426 \\
\hline F-test & $4.342^{* * *}$ & $3.976^{* * *}$ & $3.951^{* * *}$ & $3.164^{* * *}$ & $3.054^{* * *}$ & $3.043^{* * *}$ & $3.206^{* * *}$ & $3.093^{* * *}$ & $3.082^{* * *}$ \\
\hline Hausman-test & $19.52^{\star *}$ & $26.46^{* * *}$ & $31.60^{* * *}$ & $19.27^{* * *}$ & $40.12^{* * *}$ & $18.52^{* *}$ & $32.02^{\star * *}$ & $25.88^{* * *}$ & $33.29^{* * *}$ \\
\hline Mean VIF & 1.60 & 1.24 & 1.87 & 1.19 & 1.95 & 1.60 & 1.21 & 1.33 & 1.41 \\
\hline
\end{tabular}

Notes: Robust standard errors in parentheses; ${ }^{*}{ }^{\star *}$, and ${ }^{\star * *}$ indicate significance at the $10 \%, 5 \%$ and $1 \%$ levels, respectively.

Additionally, there is another argument concerning the business ethics of female board members that justifies our findings. According to Bernardi and Arnold (1997) female decision makers are at a significantly higher average level of moral development than their male counterparties which helps to improve the quality of reported earnings. 
Besides, firm characteristics also affect earning management practices (Barua et al., 2010; Ye, Zhang, \& Rezaee, 2010). In Table 5, it is observed that firm size and profitability have an effect over the dependent variable. In the first case, firm size has a mixed effect. On the one hand, when the proxy used for earnings management corresponds to the operating accruals (EM1), we observe that it increases as the firm dimension increases too. However, on the other hand, when more accurate measures of earnings management are used-such as EM2 and EM3-which consider the discretionary component of the total accruals rather than just the gross total accruals, bigger firms (Size) constrain the managerial discretionary behavior. These findings disclose that the potential opportunistic conduct of managers is mitigated as the company grows. This is in line with the fact that bigger firms are more closely monitored and followed by analysts, reducing the room for potential managerial misbehavior (Hassan \& Skinner, 2016).

Regarding the firm's profitability $(R O A)$, our results show a negative correlation between this variable and earnings management practices. Managers running more profitable companies have less incentives to overstate the firm performance, and consequently they engage less in manipulating the earnings in one or another direction.

Table 6 provides robustness checks of our preliminary results by controlling for the potential skewedness usually observed in using FE specifications due the potential endogeneity problems and the minor problems of heteroskedasticity observed in estimations 1 and 3 in Table 5 through the Generalized Methods of Moments (GMM-SE) ${ }^{8}$. In Table 6 we specifically controlled for those covariates that a priori are considered as endogenous variables. In our case, and following previous empirical literature, GD1, Bsize, Bindep, and Own are considered endogenous variables for which proper instruments are created based on their lagged values.

In Tables 6 we find further evidence of the negative impact of gender diversity (GD1) in the managerial discretionary behavior materialized in earnings management. Another relevant firm-specific characteristic is the company's leverage (Lev) level. The findings indicate that corporate indebtedness exerts a negative influence on the practices of earnings management. This result is supported by the agency theory approach. As argued by Jensen and Meckling (1976), high levels of debt reduce the firm's free cash-flow that otherwise might be used opportunistically by managers in suboptimal decisions such as private rent seeking, exerting a negative impact on discretionary accruals. Similarly, the arguments of the delegate monitoring (Berlin \& Loeys, 1988) fit with our findings, suggesting that European indexed companies are tightly monitored by financial institutions through restricted debt covenants. This idea is supported by the relevant role played by the financial institutions in civil-law countries, due to the more intensive use of bank debt than public debt.

The corporate ownership concentration $(\mathrm{Own})$ is another variable that deserves to be analyzed. Own variable is statistically significant in Table 6 for the estimates that consider the discretionary accruals as a proxy for earnings management (e.g. EM2 and EM3). Estimations $5,6,8$ and 9 show that the managerial discretionary capacity is mitigated as the voting rights of the majority shareholder increase. The existence of concentrated ownership structures contributes to the solution of certain collective action conflicts, such as the free-rider problem, by endowing the majority shareholders with proper incentives for managerial supervision

\footnotetext{
${ }^{8}$ Detected through the Modified Wald test for groupwise heteroskedasticity.
} 
Table 6. Women on board and earnings management (GMM regressions)

\begin{tabular}{|c|c|c|c|c|c|c|c|c|c|}
\hline \multirow{2}{*}{ Variables } & (1) & (2) & (3) & (4) & (5) & (6) & (7) & (8) & (9) \\
\hline & \multicolumn{3}{|c|}{$E M 1$} & \multicolumn{3}{|c|}{ EM2 } & \multicolumn{3}{|c|}{ EM3 } \\
\hline$E M 1_{t-1}$ & $\begin{array}{c}0.0886 \\
(1.2302)\end{array}$ & $\begin{array}{c}0.0400 \\
(0.5705)\end{array}$ & $\begin{array}{c}0.0424 \\
(0.5967)\end{array}$ & & & & & & \\
\hline$E M 2_{t-1}$ & & & & $\begin{array}{c}0.0612 \\
(0.5997)\end{array}$ & $\begin{array}{c}0.0023 \\
(0.0227)\end{array}$ & $\begin{array}{c}0.0043 \\
(0.0427)\end{array}$ & & & \\
\hline$E M 3_{t-1}$ & & & & & & & $\begin{array}{c}0.0651 \\
(0.6244)\end{array}$ & $\begin{array}{c}0.0063 \\
(0.0623)\end{array}$ & $\begin{array}{c}0.0075 \\
(0.0733)\end{array}$ \\
\hline GD1 & $\begin{array}{l}-1.8491^{\star *} \\
(-2.4014)\end{array}$ & $\begin{array}{l}-1.4834^{\star *} \\
(-2.1620)\end{array}$ & $\begin{array}{l}-1.4418^{\star *} \\
(-2.1523)\end{array}$ & $\begin{array}{c}-0.0554^{*} \\
(-1.7646)\end{array}$ & $\begin{array}{l}-0.0596^{* *} \\
(-2.0083)\end{array}$ & $\begin{array}{l}-0.0588^{\star *} \\
(-2.0131)\end{array}$ & $\begin{array}{l}-0.0532^{*} \\
(-1.6693)\end{array}$ & $\begin{array}{l}-0.0575^{*} \\
(-1.9145)\end{array}$ & $\begin{array}{l}-0.0566^{*} \\
(-1.9159)\end{array}$ \\
\hline Bsize & $\begin{array}{c}-0.2451 \\
(-0.7726)\end{array}$ & $\begin{array}{c}-0.1338 \\
(-0.4547)\end{array}$ & $\begin{array}{c}-0.1283 \\
(-0.4369)\end{array}$ & $\begin{array}{l}-0.0315^{\star *} \\
(-2.1150)\end{array}$ & $\begin{array}{l}-0.0253^{*} \\
(-1.6959)\end{array}$ & $\begin{array}{l}-0.0253^{*} \\
(-1.6686)\end{array}$ & $\begin{array}{l}-0.0317^{\star *} \\
(-2.1297)\end{array}$ & $\begin{array}{l}-0.0251^{*} \\
(-1.6757)\end{array}$ & $\begin{array}{c}-0.0249 \\
(-1.6431)\end{array}$ \\
\hline Bindep & & $\begin{array}{c}-0.2479 \\
(-0.7312)\end{array}$ & $\begin{array}{c}-0.2828 \\
(-0.8131)\end{array}$ & & $\begin{array}{c}-0.0080 \\
(-0.4990)\end{array}$ & $\begin{array}{c}-0.0083 \\
(-0.5122)\end{array}$ & & $\begin{array}{c}-0.0086 \\
(-0.5278)\end{array}$ & $\begin{array}{c}-0.0089 \\
(-0.5419)\end{array}$ \\
\hline Own & $\begin{array}{c}-1.6057 \\
(-1.3854)\end{array}$ & $\begin{array}{c}-2.2091 \\
(-1.8319)\end{array}$ & $\begin{array}{c}-2.2040 \\
(-1.8245)\end{array}$ & $\begin{array}{c}0.0025 \\
(0.0758)\end{array}$ & $\begin{array}{l}-0.0145^{*} \\
(-0.3926)\end{array}$ & $\begin{array}{l}-0.0138^{*} \\
(-0.3706)\end{array}$ & $\begin{array}{c}0.0041 \\
(0.1243)\end{array}$ & $\begin{array}{l}-0.0139^{*} \\
(-0.3743)\end{array}$ & $\begin{array}{l}-0.0136^{*} \\
(-0.3637)\end{array}$ \\
\hline Size & $\begin{array}{c}-0.2057 \\
(-0.5729)\end{array}$ & $\begin{array}{c}0.0560 \\
(0.2027)\end{array}$ & $\begin{array}{c}0.1066 \\
(0.3888)\end{array}$ & $\begin{array}{c}-0.0003 \\
(-0.0302)\end{array}$ & $\begin{array}{c}-0.0030 \\
(-0.2563)\end{array}$ & $\begin{array}{c}-0.0033 \\
(-0.2817)\end{array}$ & $\begin{array}{c}-0.0001 \\
(-0.0092)\end{array}$ & $\begin{array}{c}-0.0045 \\
(-0.3714)\end{array}$ & $\begin{array}{c}-0.0045 \\
(-0.3817)\end{array}$ \\
\hline$T Q$ & $\begin{array}{c}0.1075 \\
(0.7342)\end{array}$ & & & $\begin{array}{c}0.0034 \\
(0.5171)\end{array}$ & & & $\begin{array}{c}0.0034 \\
(0.5084)\end{array}$ & & \\
\hline MTB & & $\begin{array}{c}0.0290 \\
(1.2170)\end{array}$ & $\begin{array}{c}0.0279 \\
(1.2089)\end{array}$ & & $\begin{array}{c}-0.0002 \\
(-0.2400)\end{array}$ & $\begin{array}{c}-0.0002 \\
(-0.2590)\end{array}$ & & $\begin{array}{c}-0.0003 \\
(-0.2723)\end{array}$ & $\begin{array}{c}-0.0003 \\
(-0.2889)\end{array}$ \\
\hline Lev & $\begin{array}{c}-1.6010 \\
(-1.6358)\end{array}$ & $\begin{array}{l}-2.6377^{\star *} \\
(-2.3672)\end{array}$ & $\begin{array}{l}-2.6875^{\star *} \\
(-2.4385)\end{array}$ & $\begin{array}{c}-0.0874^{* * *} \\
(-2.5796)\end{array}$ & $\begin{array}{l}-0.0776^{* *} \\
(-2.0864)\end{array}$ & $\begin{array}{l}-0.0758^{\star *} \\
(-2.0166)\end{array}$ & $\mid \begin{array}{c}-0.0906^{\star * *} \\
(-2.6092)\end{array}$ & $\begin{array}{l}-0.0795^{\star *} \\
(-2.0712)\end{array}$ & $\begin{array}{l}-0.0783^{* *} \\
(-2.0203)\end{array}$ \\
\hline$Z$ & $\begin{array}{c}-0.1114 \\
(-1.1506)\end{array}$ & $\begin{array}{l}-0.1475^{\star} \\
(-1.8295)\end{array}$ & $\begin{array}{c}-0.1415^{\star} \\
(-1.8973)\end{array}$ & $\begin{array}{c}-0.0034 \\
(-1.2083)\end{array}$ & $\begin{array}{c}-0.0019 \\
(-0.8819)\end{array}$ & $\begin{array}{c}-0.0021 \\
(-0.9498)\end{array}$ & $\begin{array}{c}-0.0033 \\
(-1.1723)\end{array}$ & $\begin{array}{c}-0.0019 \\
(-0.8636)\end{array}$ & $\begin{array}{c}-0.0020 \\
(-0.9216)\end{array}$ \\
\hline$R O A$ & $\begin{array}{c}-3.1977^{\star * *} \\
(-2.9791)\end{array}$ & $\begin{array}{c}-3.3486^{\star * *} \\
(-3.1531)\end{array}$ & $\begin{array}{c}-3.3285^{* * *} \\
(-3.0986)\end{array}$ & $\begin{array}{c}-0.0470 \\
(-1.5972)\end{array}$ & $\begin{array}{c}-0.0405 \\
(-1.3619)\end{array}$ & $\begin{array}{c}-0.0413 \\
(-1.3876)\end{array}$ & $\begin{array}{c}-0.0475 \\
(-1.5353)\end{array}$ & $\begin{array}{c}-0.0394 \\
(-1.2642)\end{array}$ & $\begin{array}{c}-0.0402 \\
(-1.2897)\end{array}$ \\
\hline$I E F$ & & $\begin{array}{c}-3.7519 \\
(-1.6459)\end{array}$ & & & $\begin{array}{c}0.0125 \\
(0.1230)\end{array}$ & & & $\begin{array}{l}-0.0037^{\star} \\
(-0.0362)\end{array}$ & \\
\hline$G E$ & & & $\begin{array}{c}0.0061 \\
(0.0110)\end{array}$ & & & $\begin{array}{l}-0.0077^{\star} \\
(-0.4480)\end{array}$ & & & $\begin{array}{l}-0.0065^{*} \\
(-0.3830)\end{array}$ \\
\hline Observations & 862 & 824 & 824 & 751 & 714 & 714 & 747 & 710 & 710 \\
\hline $\begin{array}{l}\text { Number of } \\
\text { iden }\end{array}$ & 167 & 166 & 166 & 165 & 164 & 164 & 163 & 162 & 162 \\
\hline Year FE & YES & YES & YES & YES & YES & YES & YES & YES & YES \\
\hline Country FE & YES & YES & YES & YES & YES & YES & YES & YES & YES \\
\hline Wald-test & 30.21 & 32.34 & 31.77 & 20.58 & 22.14 & 21.99 & 20.34 & 21.67 & 21.62 \\
\hline Mean VIF & 1.33 & 1.36 & 1.40 & 1.28 & 1.77 & 1.38 & 1.31 & 1.20 & 1.73 \\
\hline
\end{tabular}

Notes: Robust standard errors in parentheses; ${ }^{*},{ }^{* *}$, and ${ }^{* * *}$ indicate significance at the $10 \%, 5 \%$ and $1 \%$ levels, respectively. 
that are not present in the case of minority shareholders (Bergström \& Rydqvist, 1990). Our results support this reasoning, that majority shareholders reduce the earnings management practices as their voting rights increase. According to the Law and Finance approach, the ownership structure features are not independent from the financial system where companies operate, and these characteristics explain many aspects of the corporate decision-making process (La Porta, Lopez-De-Silanes, \& Shleifer, 1999; La Porta, Lopez-De-Silanes, Shleifer, \& Vishny, 1997, 1998). With the exception of the UK, all of the countries included in our sample belong to the civil-law legal system where the rights of the shareholders are not properly protected (La Porta et al., 1998), which tends to drive greater ownership concentration as substitution mechanisms for weak legal protection of investors' rights (López \& Saona, 2005). Consequently, our results support the fact that such relatively greater concentration of the ownership leads to better monitoring and lower misreporting of the financial information.

Contextual variables such as government effectiveness $(G E)$ and the index of economic freedom (IEF) provide some results, although not as robust as those found based on the firm characteristics. For instance, the worldwide governance indicator of government effectiveness $(G E)$ is only significant in the sixth and ninth models of Table 6. This finding suggests that as the governance indicators such as regulatory system and political stability improve at the national level, the manipulation of the financial statements decreases.

Likewise, when the index of economic freedom (IEF) is used, we also find some weak evidence of this variable on earnings manipulation. In Table 5 for instance, the relationship is negative and statistically significant in Model 2, suggesting that as the barrier to international trade, the regulation, and the enforcement of the law improves, there is less room for managers to misreport the financial information. Similar findings are observed in Tables 6, Model 8.

Different from previous findings, Table 6 also provides additional information on the hypothesis of persistency in earnings management practices. As observed in the nine alternative models, none of them report significant coefficient for the one-period lagged dependent variable, and consequently, we reject the persistency of the earnings manipulation in the context of selected European corporations. The remaining results in Table 8 can be used as robustness checks for our previous findings.

Finally, in Table 7 we used our two alternatives and more suitable measures of gender diversity (see GD2 and GD3 variables). For space saving reasons, we recurred only to the results based on the GMM-SE panel data, but all the other specifications (FE, F-GSL and PCSE) were also computed and their results remained consistent with those already shown in Table 7. The findings in this table confirm the negative relation between gender diversity and EM practices, as observed in the previous tables. The main idea extracted from this table is that equilibrated diversity in the board has a deterrent effect over earnings management practices, benefiting the earnings quality reported. In this case, and following Blau (1977), Shannon (1948), Abad et al. (2017), Martín-Ugedo and Minguez-Vera (2014) and Baumgärtner (2006), our gender measures are more than just women on board measures, these are rather diversity measures, making reference to equilibrated board in terms of women/men presence.

Related to the others independent variables, the results hold.

All the arguments presented in previous tables from multivariate analysis, confirm that more female presence at the board of directors will lead to less earnings manipulation, consistent with the Hypothesis 1. 
Table 7. Gender diversity and earnings management (GMM regressions)

\begin{tabular}{|c|c|c|c|c|c|c|c|c|c|c|c|c|}
\hline \multirow{2}{*}{ Variables } & (1) & (2) & (3) & (4) & (5) & (6) & (7) & (8) & (9) & (10) & (11) & (12) \\
\hline & EM1 & $E M 1$ & EM2 & $E M 2$ & EM3 & EM3 & $E M 1$ & $E M 1$ & EM2 & $E M 2$ & EM3 & EM3 \\
\hline$E M 1_{t-1}$ & $\begin{array}{c}0.0287 \\
(0.4205)\end{array}$ & $\begin{array}{c}0.0309 \\
(0.4478)\end{array}$ & & & & & $\begin{array}{c}0.0255 \\
(0.3783)\end{array}$ & $\begin{array}{c}0.0277 \\
(0.4060)\end{array}$ & & & & \\
\hline$E M 2_{t-1}$ & & & $\begin{array}{l}-0.0097 \\
(-0.0990)\end{array}$ & $\mid \begin{array}{c}-0.0078 \\
(-0.0794)\end{array}$ & & & & & $\begin{array}{c}-0.0123 \\
(-0.1257)\end{array}$ & $\begin{array}{c}-0.0105 \\
(-0.1064)\end{array}$ & & \\
\hline$E M 3_{t-1}$ & & & & & $\begin{array}{c}-0.0057 \\
(-0.0575)\end{array}$ & $\mid \begin{array}{c}-0.0047 \\
(-0.0472)\end{array}$ & & & & & $\begin{array}{c}-0.0082 \\
(-0.0826)\end{array}$ & $\begin{array}{c}-0.0073 \\
(-0.0724)\end{array}$ \\
\hline GD2 & $\left|\begin{array}{c}-1.4012^{\star *} \\
(-2.2231)\end{array}\right|$ & $\left|\begin{array}{c}-1.3714^{* *} \\
(-2.2306)\end{array}\right|$ & $\begin{array}{l}-0.0655^{* *} \\
(-2.5365)\end{array}$ & $\left|\begin{array}{c}-0.0645^{* *} \\
(-2.5543)\end{array}\right|$ & $\left|\begin{array}{c}-0.0637^{* *} \\
(-2.4348)\end{array}\right|$ & $\begin{array}{c}-0.0627^{* *} \\
(-2.4502)\end{array}$ & & & & & & \\
\hline GD3 & & & & & & & $\begin{array}{l}-1.0673^{* *} \\
(-2.2418)\end{array}$ & $\left|\begin{array}{c}-1.0481^{\star *} \\
(-2.2487)\end{array}\right|$ & $\begin{array}{c}-0.0509^{* * *} \\
(-2.6116)\end{array}$ & $\left|\begin{array}{c}-0.0502^{* * *} \\
(-2.6325)\end{array}\right|$ & $\left|\begin{array}{c}-0.0494^{* *} \\
(-2.4990)\end{array}\right|$ & $\begin{array}{c}-0.0486^{* \star} \\
(-2.5173)\end{array}$ \\
\hline Bsize & $\begin{array}{c}-0.1336 \\
(-0.4493)\end{array}$ & $\begin{array}{c}-0.1268 \\
(-0.4286)\end{array}$ & $\begin{array}{l}-0.0253^{*} \\
(-1.6920)\end{array}$ & $\begin{array}{l}-0.0252^{\star} \\
(-1.6593)\end{array}$ & $\begin{array}{l}-0.0250^{*} \\
(-1.6669)\end{array}$ & $\begin{array}{c}-0.0248 \\
(-1.6290)\end{array}$ & $\begin{array}{c}-0.1263 \\
(-0.4227)\end{array}$ & $\left|\begin{array}{c}-0.1182 \\
(-0.3985)\end{array}\right|$ & $\begin{array}{l}-0.0249^{*} \\
(-1.6584)\end{array}$ & $\begin{array}{c}-0.0247 \\
(-1.6221)\end{array}$ & $\begin{array}{c}-0.0247 \\
(-1.6335)\end{array}$ & $\begin{array}{c}-0.0244 \\
(-1.5915)\end{array}$ \\
\hline Bindep & $\begin{array}{c}-0.2454 \\
(-0.7293)\end{array}$ & $\begin{array}{c}-0.2856 \\
(-0.8231)\end{array}$ & $\begin{array}{l}-0.0083 \\
(-0.5137)\end{array}$ & $\mid \begin{array}{c}-0.0087 \\
(-0.5342)\end{array}$ & $\begin{array}{c}-0.0089 \\
(-0.5433)\end{array}$ & $\begin{array}{c}-0.0093 \\
(-0.5652)\end{array}$ & $\begin{array}{c}-0.2520 \\
(-0.7439)\end{array}$ & $\begin{array}{c}-0.2939 \\
(-0.8412)\end{array}$ & $\begin{array}{c}-0.0086 \\
(-0.5316)\end{array}$ & $\begin{array}{c}-0.0090 \\
(-0.5533)\end{array}$ & $\begin{array}{c}-0.0092 \\
(-0.5593)\end{array}$ & $\mid \begin{array}{c}-0.0096 \\
(-0.5830)\end{array}$ \\
\hline Own & $\begin{array}{c}-2.1942^{*} \\
(-1.8455)\end{array}$ & $\begin{array}{l}-2.2003^{*} \\
(-1.8502)\end{array}$ & $\begin{array}{l}-0.0151 \\
(-0.4075)\end{array}$ & $\begin{array}{c}-0.0145 \\
(-0.3902)\end{array}$ & $\begin{array}{c}-0.0143 \\
(-0.3850)\end{array}$ & $\begin{array}{c}-0.0142 \\
(-0.3796)\end{array}$ & $\begin{array}{l}-2.1948^{*} \\
(-1.8647)\end{array}$ & $\begin{array}{l}-2.2014^{*} \\
(-1.8678)\end{array}$ & $\begin{array}{c}-0.0157 \\
(-0.4229)\end{array}$ & $\begin{array}{c}-0.0153 \\
(-0.4103)\end{array}$ & $\mid \begin{array}{c}-0.0149 \\
(-0.3993)\end{array}$ & $\mid \begin{array}{c}-0.0149 \\
(-0.3986)\end{array}$ \\
\hline Size & $\begin{array}{c}0.0817 \\
(0.2927)\end{array}$ & $\begin{array}{c}0.1366 \\
(0.4937)\end{array}$ & $\begin{array}{l}-0.0005 \\
(-0.0475)\end{array}$ & $\begin{array}{c}-0.0007 \\
(-0.0620)\end{array}$ & $\begin{array}{c}-0.0020 \\
(-0.1686)\end{array}$ & $\begin{array}{c}-0.0019 \\
(-0.1668)\end{array}$ & $\begin{array}{c}0.0797 \\
(0.2832)\end{array}$ & $\begin{array}{c}0.1351 \\
(0.4841)\end{array}$ & $\begin{array}{c}-0.0004 \\
(-0.0338)\end{array}$ & $\begin{array}{c}-0.0004 \\
(-0.0387)\end{array}$ & $\begin{array}{c}-0.0018 \\
(-0.1572)\end{array}$ & $\begin{array}{c}-0.0017 \\
(-0.1460)\end{array}$ \\
\hline Lev & $\begin{array}{c}-2.6592^{* *} \\
(-2.3800)\end{array}$ & $\left|\begin{array}{c}-2.7133^{* *} \\
(-2.4592)\end{array}\right|$ & $\begin{array}{l}-0.0824^{* *} \\
(-2.2191)\end{array}$ & $\left|\begin{array}{c}-0.0807^{* *} \\
(-2.1590)\end{array}\right|$ & $\begin{array}{c}-0.0841^{* *} \\
(-2.1946)\end{array}$ & $\begin{array}{c}-0.0831^{* *} \\
(-2.1520)\end{array}$ & $\begin{array}{c}-2.6438^{* *} \\
(-2.3596)\end{array}$ & $\left|\begin{array}{c}-2.6980^{* *} \\
(-2.4416)\end{array}\right|$ & $\begin{array}{c}-0.0828^{* *} \\
(-2.2362)\end{array}$ & $\left|\begin{array}{c}-0.0813^{* *} \\
(-2.1840)\end{array}\right|$ & $\left|\begin{array}{c}-0.0846^{* *} \\
(-2.2108)\end{array}\right|$ & $\left|\begin{array}{c}-0.0837^{* *} \\
(-2.1747)\end{array}\right|$ \\
\hline$Z$ & $\begin{array}{l}-0.1426^{*} \\
(-1.7922)\end{array}$ & $\begin{array}{l}-0.1354^{*} \\
(-1.8530)\end{array}$ & $\begin{array}{l}-0.0020 \\
(-0.9157)\end{array}$ & $\mid \begin{array}{c}-0.0021 \\
(-0.9643)\end{array}$ & $\begin{array}{c}-0.0020 \\
(-0.8910)\end{array}$ & $\begin{array}{c}-0.0020 \\
(-0.9298)\end{array}$ & $\begin{array}{l}-0.1402^{*} \\
(-1.7704)\end{array}$ & $\left|\begin{array}{l}-0.1328^{*} \\
(-1.8286)\end{array}\right|$ & $\begin{array}{c}-0.0020 \\
(-0.9196)\end{array}$ & $\begin{array}{c}-0.0021 \\
(-0.9607)\end{array}$ & $\begin{array}{c}-0.0020 \\
(-0.8949)\end{array}$ & $\begin{array}{c}-0.0020 \\
(-0.9255)\end{array}$ \\
\hline$R O A$ & $\left|\begin{array}{c}-3.3243^{* * *} \\
(-3.1552)\end{array}\right|$ & $\mid \begin{array}{c}-3.3025^{* * *} \\
(-3.0971)\end{array}$ & $\begin{array}{l}-0.0392 \\
(-1.3324)\end{array}$ & $\left|\begin{array}{c}-0.0401 \\
(-1.3604)\end{array}\right|$ & $\begin{array}{c}-0.0380 \\
(-1.2337)\end{array}$ & $\begin{array}{c}-0.0390 \\
(-1.2632)\end{array}$ & $\begin{array}{c}-3.2992^{* * *} \\
(-3.1410)\end{array}$ & $\left|\begin{array}{c}-3.2774^{* * *} \\
(-3.0832)\end{array}\right|$ & $\begin{array}{c}-0.0383 \\
(-1.3026)\end{array}$ & $\begin{array}{c}-0.0392 \\
(-1.3333)\end{array}$ & $\begin{array}{c}-0.0370 \\
(-1.2033)\end{array}$ & $\mid \begin{array}{c}-0.0381 \\
(-1.2364)\end{array}$ \\
\hline MTB & $\begin{array}{c}0.0295 \\
(1.2378)\end{array}$ & $\begin{array}{c}0.0283 \\
(1.2261)\end{array}$ & $\begin{array}{c}-0.0001 \\
(-0.0724)\end{array}$ & $\begin{array}{c}-0.0001 \\
(-0.0974)\end{array}$ & $\begin{array}{c}-0.0001 \\
(-0.1014)\end{array}$ & $\begin{array}{c}-0.0001 \\
(-0.1242)\end{array}$ & $\begin{array}{c}0.0297 \\
(1.2478)\end{array}$ & $\begin{array}{c}0.0285 \\
(1.2357)\end{array}$ & $\begin{array}{c}-0.0000 \\
(-0.0316)\end{array}$ & $\begin{array}{c}-0.0001 \\
(-0.0589)\end{array}$ & $\begin{array}{c}-0.0001 \\
(-0.0594)\end{array}$ & $\mid \begin{array}{c}-0.0001 \\
(-0.0850)\end{array}$ \\
\hline$I E F$ & $\begin{array}{c}-3.9733^{*} \\
(-1.7398)\end{array}$ & & $\begin{array}{c}0.0020 \\
(0.0196)\end{array}$ & & $\begin{array}{c}-0.0150 \\
(-0.1446)\end{array}$ & & $\begin{array}{l}-3.9603^{*} \\
(-1.7581)\end{array}$ & & $\begin{array}{c}-0.0042 \\
(-0.0408)\end{array}$ & & $\begin{array}{c}-0.0214 \\
(-0.2046)\end{array}$ & \\
\hline$G E$ & & $\begin{array}{c}0.0463 \\
(0.0835)\end{array}$ & & $\begin{array}{c}-0.0059 \\
(-0.3451)\end{array}$ & & $\begin{array}{c}-0.0048 \\
(-0.2834)\end{array}$ & & $\begin{array}{c}0.0625 \\
(0.1119)\end{array}$ & & $\begin{array}{c}-0.0055 \\
(-0.3195)\end{array}$ & & $\begin{array}{l}-0.0044 \\
(-0.2570)\end{array}$ \\
\hline Observations & 824 & 824 & 714 & 714 & 710 & 710 & 824 & 824 & 714 & 714 & 710 & 710 \\
\hline $\begin{array}{l}\text { Number of } \\
\text { iden }\end{array}$ & 166 & 166 & 164 & 164 & 162 & 162 & 166 & 166 & 164 & 164 & 162 & 162 \\
\hline Year FE & YES & YES & YES & YES & YES & YES & YES & YES & YES & YES & YES & YES \\
\hline Country FE & YES & YES & YES & YES & YES & YES & YES & YES & YES & YES & YES & YES \\
\hline Wald-test & 32.77 & 31.97 & 26.43 & 26.37 & 25.60 & 25.73 & 32.95 & 32.06 & 27.47 & 27.37 & 26.47 & 26.60 \\
\hline Mean VIF & 1.75 & 1.97 & 1.78 & 2.28 & 1.92 & 1.19 & 1.79 & 1.72 & 1.80 & 1.55 & 1.29 & 1.62 \\
\hline
\end{tabular}

Notes: Robust standard errors in parentheses; ${ }^{\star},{ }^{\star *}$, and ${ }^{\star * *}$ indicate significance at the $10 \%, 5 \%$ and $1 \%$ levels, respectively. 


\subsubsection{The impact of female quotas on earnings management}

This part of the analysis is focused on assessing the extent to which female quotas on the board of director stated by law or corporate governance codes across countries impact the earnings management practices.

Table 8 has been intended to consider the interacted relation between gender diversity and quotas and their joint impact on the earnings management practices. In regressions 3 through 6 for GD2 and in regressions 9 to 12 for GD3, the lineal combination between gender diversity measures and quotas requirements (GD2+GD2 ${ }^{\star}$ Quota and GD2+GD2* Quota ) show significant coefficients and with a greater economic impact than the stand-alone gender diversity measures (GD2 and GD3, respectively). In this sense, the case of regressions 3 to 6 , when gender diversity increases $10.00 \%$ and gender quota exists, the joint impact over earnings management practices decreases by $7.09 \%$, computed as the mean among the significant coefficients computed as GD2+GD2* Quota. Hence, this table shows evidence supporting the female quota indications passed in the last decades in some countries in Europe as a means to increase financial reporting transparency. We can state, therefore, that in countries where female quota indications (by law or recommendation) exist, the impact of gender diversity has been more prominent in diminishing earnings manipulation practices than in countries where these kinds of recommendations do not exist. Therefore, the efforts in carrying out these measures in European countries have helped to constraint active earnings manipulation, consistent with Hypothesis 2.

Table 8. Gender diversity and quotas and earnings management (GMM regressions)

\begin{tabular}{|c|c|c|c|c|c|c|c|c|c|c|c|c|}
\hline \multirow{2}{*}{ Variables } & (1) & (2) & (3) & (4) & (5) & (6) & (7) & (8) & (9) & (10) & (11) & (12) \\
\hline & EM2 & EM2 & $E M 4$ & EM4 & EM5 & EM5 & $E M 2$ & $E M 2$ & $E M 4$ & EM4 & EM5 & EM5 \\
\hline$E M 1_{t-1}$ & $\begin{array}{c}0.0240 \\
(0.3563)\end{array}$ & $\begin{array}{c}0.0261 \\
(0.3828)\end{array}$ & & & & & $\begin{array}{c}0.0213 \\
(0.3208)\end{array}$ & \begin{tabular}{|c|}
0.0233 \\
$(0.3464)$
\end{tabular} & & & & \\
\hline$E M 2_{t-1}$ & & & $\begin{array}{l}-0.0222 \\
(-0.2290)\end{array}$ & $\begin{array}{c}-0.0203 \\
(-0.2089)\end{array}$ & & & & & $\begin{array}{c}-0.0255 \\
(-0.2645)\end{array}$ & $\mid \begin{array}{c}-0.0238 \\
(-0.2451)\end{array}$ & & \\
\hline$E M 3_{t-1}$ & & & & & $\begin{array}{c}-0.0182 \\
(-0.1845)\end{array}$ & $\begin{array}{l}-0.0172 \\
(-0.1734)\end{array}$ & & & & & $\begin{array}{l}-0.0214 \\
(-0.2183)\end{array}$ & $\begin{array}{l}-0.0205 \\
(-0.2076)\end{array}$ \\
\hline GD2 & $\begin{array}{c}-1.6467^{* *} \\
(-2.3466)\end{array}$ & $\left|\begin{array}{c}-1.5594^{* *} \\
(-2.2401)\end{array}\right|$ & $\mid \begin{array}{c}-0.0604^{* *} \\
(-2.2166)\end{array}$ & $\begin{array}{c}-0.0604^{* \star} \\
(-2.2809)\end{array} \mid$ & $\left|\begin{array}{c}-0.0592^{\star *} \\
(-2.1460)\end{array}\right|$ & $\left|\begin{array}{c}-0.0590^{* *} \\
(-2.2008)\end{array}\right|$ & & & & & & \\
\hline$G D 2^{\star}$ Quota & $\begin{array}{c}0.4971 \\
(0.9477)\end{array}$ & $\begin{array}{c}0.3825 \\
(0.7201)\end{array}$ & $\begin{array}{c}-0.0126 \\
(-0.6859)\end{array}$ & $\begin{array}{c}-0.0107 \\
(-0.6157)\end{array}$ & $\mid \begin{array}{c}-0.0109 \\
(-0.5920)\end{array}$ & $\begin{array}{l}-0.0095 \\
(-0.5512)\end{array}$ & & & & & & \\
\hline $\begin{array}{l}G D 2+ \\
G D 2^{*} \text { Quota }\end{array}$ & -1.1496 & -1.1769 & $-0.0731^{*}$ & $-0.0711^{* *}$ & $-0.0701^{\star *}$ & $-0.0685^{*}$ & & & & & & \\
\hline GD3 & & & & & & & $\begin{array}{c}-1.2348^{* *} \\
(-2.3748)\end{array}$ & $\begin{array}{c}-1.1765^{* *} \\
(-2.2806)\end{array}$ & $\left|\begin{array}{c}-0.0478^{* *} \\
(-2.3100)\end{array}\right|$ & $\left|\begin{array}{c}-0.0476^{* \star} \\
(-2.3710)\end{array}\right|$ & $\begin{array}{c}-0.0466^{* *} \\
(-2.2241)\end{array}$ & $\begin{array}{l}-0.0463^{* *} \\
(-2.2764)\end{array}$ \\
\hline GD $3^{\star}$ Quota & & & & & & & $\begin{array}{c}0.3405 \\
(0.9557)\end{array}$ & $\begin{array}{c}0.2657 \\
(0.7393)\end{array}$ & $\begin{array}{c}-0.0072 \\
(-0.5751)\end{array}$ & $\begin{array}{c}-0.0061 \\
(-0.5197)\end{array}$ & $\begin{array}{c}-0.0061 \\
(-0.4934)\end{array}$ & $\begin{array}{l}-0.0055 \\
(-0.4670)\end{array}$ \\
\hline $\begin{array}{l}\text { GD3 + } \\
\text { GD3* Quota }\end{array}$ & & & & & & & -0.8943 & -0.9108 & $-0.0549^{* *}$ & $-0.0537^{* *}$ & $-0.0527^{* * *}$ & $-0.0518^{* *}$ \\
\hline Bsize & $\begin{array}{l}-0.0599 \\
(-0.1987)\end{array}$ & $\left|\begin{array}{c}-0.0671 \\
(-0.2217)\end{array}\right|$ & $\left|\begin{array}{l}-0.0273^{*} \\
(-1.8156)\end{array}\right|$ & $\begin{array}{c}-0.0271^{*} \\
(-1.7818)\end{array}$ & $\begin{array}{l}-0.0268^{*} \\
(-1.7764)\end{array}$ & $\left|\begin{array}{l}-0.0265^{*} \\
(-1.7422)\end{array}\right|$ & $\begin{array}{c}-0.0500 \\
(-0.1646)\end{array}$ & $\begin{array}{c}-0.0555 \\
(-0.1822)\end{array}$ & $\begin{array}{l}-0.0265^{\star} \\
(-1.7554)\end{array}$ & $\begin{array}{l}-0.0263^{*} \\
(-1.7202)\end{array}$ & $\begin{array}{l}-0.0261^{*} \\
(-1.7169)\end{array}$ & $\begin{array}{l}-0.0257^{*} \\
(-1.6812)\end{array}$ \\
\hline
\end{tabular}


End of Table 8

\begin{tabular}{|c|c|c|c|c|c|c|c|c|c|c|c|c|}
\hline \multirow{2}{*}{ Variables } & (1) & (2) & (3) & (4) & (5) & (6) & (7) & (8) & (9) & (10) & (11) & (12) \\
\hline & EM2 & EM2 & EM4 & EM4 & EM5 & EM5 & EM2 & EM2 & EM4 & EM4 & EM5 & EM5 \\
\hline Bindep & $\begin{array}{c}-0.2690 \\
(-0.8034)\end{array}$ & $\mid \begin{array}{c}-0.2832 \\
(-0.8210)\end{array}$ & $\begin{array}{c}-0.0080 \\
(-0.4955)\end{array}$ & $\mid \begin{array}{c}-0.0079 \\
(-0.4927)\end{array}$ & $\begin{array}{c}-0.0085 \\
(-0.5254)\end{array}$ & $\begin{array}{l}-0.0085 \\
(-0.5231)\end{array}$ & $\mid \begin{array}{c}-0.2712 \\
(-0.8045)\end{array}$ & $\left|\begin{array}{c}-0.2864 \\
(-0.8245)\end{array}\right|$ & $\begin{array}{c}-0.0082 \\
(-0.5094)\end{array}$ & $\left|\begin{array}{c}-0.0082 \\
(-0.5070)\end{array}\right|$ & $\begin{array}{c}-0.0088 \\
(-0.5379)\end{array}$ & $\begin{array}{c}-0.0088 \\
(-0.5365)\end{array}$ \\
\hline Own & $\begin{array}{l}-2.1532^{\star} \\
(-1.8090)\end{array}$ & $\begin{array}{l}-2.1695^{*} \\
(-1.8252)\end{array}$ & $\begin{array}{c}-0.0148 \\
(-0.4026)\end{array}$ & $\begin{array}{c}-0.0144 \\
(-0.3900)\end{array}$ & $\begin{array}{c}-0.0139 \\
(-0.3783)\end{array}$ & \begin{tabular}{|l|}
-0.0140 \\
$(-0.3774)$
\end{tabular} & $\mid \begin{array}{l}-2.1443^{*} \\
(-1.8172)\end{array}$ & $\begin{array}{l}-2.1631^{*} \\
(-1.8330)\end{array} \mid$ & $\mid \begin{array}{c}-0.0152 \\
(-0.4147)\end{array}$ & $\left|\begin{array}{c}-0.0150 \\
(-0.4072)\end{array}\right|$ & $\begin{array}{c}-0.0143 \\
(-0.3877)\end{array}$ & $\begin{array}{c}-0.0145 \\
(-0.3918)\end{array}$ \\
\hline Size & $\begin{array}{c}0.0669 \\
(0.2348)\end{array}$ & $\begin{array}{c}0.1354 \\
(0.4844)\end{array}$ & $\begin{array}{c}0.0002 \\
(0.0208)\end{array}$ & $\begin{array}{c}-0.0002 \\
(-0.0155)\end{array}$ & $\begin{array}{c}-0.0013 \\
(-0.1113)\end{array}$ & \begin{tabular}{|l|}
-0.0015 \\
$(-0.1273)$
\end{tabular} & $\begin{array}{c}0.0619 \\
(0.2152)\end{array}$ & $\begin{array}{c}0.1311 \\
(0.4638)\end{array}$ & $\begin{array}{c}0.0004 \\
(0.0331)\end{array}$ & $\begin{array}{c}0.0001 \\
(0.0067)\end{array}$ & $\begin{array}{c}-0.0012 \\
(-0.1012)\end{array}$ & $\begin{array}{l}-0.0012 \\
(-0.1077)\end{array}$ \\
\hline Lev & $\begin{array}{l}-2.6373^{* *} \\
(-2.3307) \\
\end{array}$ & $\begin{array}{c}-2.6961^{* *} \\
(-2.4289)\end{array} \mid$ & $\begin{array}{l}-0.0838^{\star \star} \\
(-2.2845)\end{array}$ & $\begin{array}{l}-0.0823^{* *} \\
(-2.2201) \\
\end{array}$ & $\begin{array}{l}-0.0857^{* *} \\
(-2.2612)\end{array}$ & \begin{tabular}{|l|}
$-0.0849^{* *}$ \\
$(-2.2152)$ \\
\end{tabular} & $\begin{array}{l}-2.6205^{\star *} \\
(-2.3116)\end{array}$ & $\begin{array}{l}-2.6789^{* *} \\
(-2.4112)\end{array}$ & $\begin{array}{l}-0.0842^{\star *} \\
(-2.2997)\end{array}$ & $\begin{array}{l}-0.0829^{* *} \\
(-2.2448)\end{array}$ & $\begin{array}{l}-0.0860^{* *} \\
(-2.2736)\end{array}$ & $\begin{array}{l}-0.0854^{* *} \\
(-2.2356)\end{array}$ \\
\hline$Z$ & $\begin{array}{l}-0.1475^{\star} \\
(-1.8129) \\
\end{array}$ & $\begin{array}{l}-0.1386^{*} \\
(-1.8725)\end{array}$ & $\begin{array}{c}-0.0020 \\
(-0.9124) \\
\end{array}$ & $\begin{array}{c}-0.0022 \\
(-0.9952) \\
\end{array}$ & $\begin{array}{c}-0.0020 \\
(-0.8974) \\
\end{array}$ & \begin{tabular}{|l|}
-0.0021 \\
$(-0.9693)$ \\
\end{tabular} & $\begin{array}{l}-0.1454^{*} \\
(-1.7934)\end{array}$ & $\begin{array}{l}-0.1364^{*} \\
(-1.8494) \\
\end{array}$ & $\begin{array}{c}-0.0020 \\
(-0.9218)\end{array}$ & \begin{tabular}{|c|}
-0.0022 \\
$(-0.9978)$
\end{tabular} & $\begin{array}{c}-0.0020 \\
(-0.9044) \\
\end{array}$ & $\begin{array}{l}-0.0021 \\
(-0.9689)\end{array}$ \\
\hline$R O A$ & $\begin{array}{l}-3.3038^{* * *} \\
(-3.1989) \\
\end{array}$ & $\left|\begin{array}{c}-3.2665^{* * *} \\
(-3.1319)\end{array}\right|$ & $\begin{array}{c}-0.0380 \\
(-1.2920)\end{array}$ & $\begin{array}{c}-0.0385 \\
(-1.3086) \\
\end{array}$ & $\begin{array}{c}-0.0367 \\
(-1.1915)\end{array}$ & \begin{tabular}{|l|}
-0.0372 \\
$(-1.2098)$ \\
\end{tabular} & $\begin{array}{l}-3.2768^{* * *} \\
(-3.1822)\end{array}$ & $\begin{array}{l}-3.2415^{* * *} \\
(-3.1164)\end{array}$ & $\begin{array}{c}-0.0371 \\
(-1.2637) \\
\end{array}$ & $\begin{array}{c}-0.0376 \\
(-1.2821)\end{array}$ & $\begin{array}{c}-0.0358 \\
(-1.1640) \\
\end{array}$ & $\begin{array}{c}-0.0364 \\
(-1.1849) \\
\end{array}$ \\
\hline MTB & $\begin{array}{c}0.0290 \\
(1.2204)\end{array}$ & $\begin{array}{c}0.0281 \\
(1.2167)\end{array}$ & $\begin{array}{c}0.0000 \\
(0.0277)\end{array}$ & $\begin{array}{c}0.0000 \\
(0.0103)\end{array}$ & $\begin{array}{c}-0.0000 \\
(-0.0025)\end{array}$ & $\begin{array}{l}-0.0000 \\
(-0.0150)\end{array}$ & $\begin{array}{c}0.0290 \\
(1.2229)\end{array}$ & $\begin{array}{l}0.0280 \\
(1.2194)\end{array}$ & $\begin{array}{c}0.0001 \\
(0.0650)\end{array}$ & $\begin{array}{l}>0.0000 \\
(0.0467)\end{array}$ & $\begin{array}{l}>0.0000 \\
(0.0345)\end{array}$ & $\begin{array}{l}>0.0000 \\
(0.0207)\end{array}$ \\
\hline IEF & \begin{tabular}{|l|}
$-4.3286^{*}$ \\
$(-1.8594)$ \\
\end{tabular} & & $\begin{array}{c}0.0186 \\
(0.1722) \\
\end{array}$ & & $\begin{array}{c}0.0004 \\
(0.0037) \\
\end{array}$ & & $\begin{array}{l}-4.3050^{*} \\
(-1.8710)\end{array}$ & & $\begin{array}{c}0.0124 \\
(0.1145)\end{array}$ & & $\begin{array}{c}-0.0055 \\
(-0.0503) \\
\end{array}$ & \\
\hline$G E$ & & $\begin{array}{c}-0.0209 \\
(-0.0385)\end{array}$ & & $\begin{array}{l}-0.0086 \\
(-0.5002) \\
\end{array}$ & & $\begin{array}{c}-0.0076 \\
(-0.4468) \\
\end{array}$ & & $\begin{array}{c}-0.0070 \\
(-0.0129) \\
\end{array}$ & & $\begin{array}{c}-0.0082 \\
(-0.4789)\end{array}$ & & $\begin{array}{l}-0.0073 \\
(-0.4229)\end{array}$ \\
\hline Observations & 824 & 824 & 714 & 714 & 710 & 710 & 824 & 824 & 714 & 714 & 710 & 710 \\
\hline $\begin{array}{l}\text { Number of } \\
\text { iden }\end{array}$ & 166 & 166 & 164 & 164 & 162 & 162 & 166 & 166 & 164 & 164 & 162 & 162 \\
\hline Year FE & YES & YES & YES & YES & YES & YES & YES & YES & YES & YES & YES & YES \\
\hline Country FE & YES & YES & YES & YES & YES & YES & YES & YES & YES & YES & YES & YES \\
\hline Wald-test & 32.54 & 31.78 & 28.46 & 28.57 & 27.12 & 27.40 & 32.94 & 31.94 & 29.26 & 29.31 & 27.78 & 28.05 \\
\hline Mean VIF & 1.34 & 1.29 & 1.73 & 1.17 & 1.70 & 1.04 & 1.28 & 1.30 & 1.95 & 1.09 & 1.28 & 1.84 \\
\hline
\end{tabular}

Notes: Robust standard errors in parentheses. ${ }^{*}{ }^{\star *}$, and ${ }^{\star * *}$ indicate significance at the $10 \%, 5 \%$ and $1 \%$ levels, respectively.

Finally, Table 9 provides a summary and holistic view our major findings. This table exhibits a synopsis of Tables 5 through 8, including the most important variables considered in the study with the sign of their respective estimations. Next to each sign we reported if such variables were or not statistically significant to know if they are subject to interpretation. The first column in Table 9 indicates the expected relationships based on our research hypotheses. As observed, the empirical analysis strongly supports the hypotheses, suggesting, on the one hand, that more female presence on the board of directors in the studied European firms leads to less earnings manipulation. On the other hand, companies manipulate less aggressively the financial reports in countries that had adopted gender quota systems than in countries which do not apply the quota systems yet.

Among other corporate governance features, the general findings indicate that board compounded by a greater number of members mitigates the discretionary behavior of managers and that the role played by the controlling shareholder is critical also in restricting the opportunistic manipulation of financial reports. The findings are robust to a number of alternative regression methods (e.g. OLS-FE, GMM-SE, F-GSL and PCSE). 
Table 9. Summary of regression outputs

\begin{tabular}{|l|c|c|c|c|c|}
\hline \multirow{2}{*}{} & \multirow{2}{*}{ Hypotheses } & Tab. 5 & Tab. 6 & Tab. 7 & Tab. 8 \\
\cline { 3 - 6 } & & OLS-FE & GMM-SE & GMM-SE & GMM-SE \\
\hline GD1 & H1: (-) & $(-)^{\mathrm{a}}$ & $(-)^{\mathrm{a}}$ & & \\
\hline GD2 or GD3 & H1: (-) & & & $(-)^{\mathrm{a}}$ & \\
\hline (GD2 or GD3) Quota & H2: (-) & & & & $(-)^{\mathrm{a}}$ \\
\hline Bsize & & $(+)^{\mathrm{b}}$ & $(-)^{\mathrm{a}}$ & $(-)^{\mathrm{a}}$ & $(-)^{\mathrm{a}}$ \\
\hline Bindep & & $(+)^{\mathrm{b}}$ & $(-)^{\mathrm{b}}$ & $(-)^{\mathrm{b}}$ & $(-)^{\mathrm{b}}$ \\
\hline Own & & $(+)^{\mathrm{b}}$ & $(-)^{\mathrm{a}}$ & $(-)^{\mathrm{a}}$ & $(-)^{\mathrm{a}}$ \\
\hline Size & & $(-/+)^{\mathrm{a}}$ & $(-)^{\mathrm{b}}$ & $(-/+)^{\mathrm{b}}$ & $(-/+)^{\mathrm{b}}$ \\
\hline TQ or MTB & & $(+)^{\mathrm{b}}$ & $(-/+)^{\mathrm{b}}$ & $(-/+)^{\mathrm{b}}$ & $(-/+)^{\mathrm{b}}$ \\
\hline Lev & & $(-/+)^{\mathrm{b}}$ & $(-)^{\mathrm{a}}$ & $(-)^{\mathrm{a}}$ & $(-)^{\mathrm{a}}$ \\
\hline Z & & $(-)^{\mathrm{b}}$ & $(-)^{\mathrm{a}}$ & $(-)^{\mathrm{a}}$ & $(-)^{\mathrm{a}}$ \\
\hline ROA & & $(-)^{\mathrm{a}}$ & $(-)^{\mathrm{a}}$ & $(-)^{\mathrm{a}}$ & $(-)^{\mathrm{a}}$ \\
\hline IEF or GE & & $(-/+)^{\mathrm{b}}$ & $(-)^{\mathrm{a}}$ & $(-)^{\mathrm{a}}$ & $(-)^{\mathrm{a}}$ \\
\hline Panel data diagnostic tests & & YES & YES & YES & YES $^{2}$ \\
\hline
\end{tabular}

Notes: ${ }^{\mathrm{a}}$ and ${ }^{\mathrm{b}}$ are statistically significant and non-statistically significant estimations, respectively.

\section{Conclusions}

Women are more adept at business ethics and risk aversion. Our findings demonstrate the beneficial effect of female board directorship in reducing earnings management. Previous research has demonstrated the strategic and valuable role played by women in corporate positions (Sila et al., 2016; Storvik \& Teigen, 2010). For instance, studies have demonstrated that women on board positively influence the board effectiveness (Adams \& Ferreira, 2009a; Chapple et al., 2018; Huse \& Solberg, 2006; Nielsen \& Huse, 2010; Pucheta Martínez et al., 2016), and the market perception of firm value (Gavious et al., 2012). This paper studies how board gender diversity influences the managerial opportunistic behavior. Specifically, we analyze the impact of board gender diversity as an instrument of corporate governance in mitigating the earnings management practices in European companies.

Our results confirm the benefits of having a balanced board in terms of gender diversity. In fact, the presence of female members mitigates earnings management practices. Moreover, the results show the relevance of legislation concerning the application of female quotas on boards in Europe.

Specifically, the results shed some light on two important aspects. First, the benefit of having a balanced board between men and women directors tends to reduce or mitigate earning management practices. Second, the beneficial effect of equilibrated boards, exposed in this first point, is even stronger in countries that have required female quotas on board of directors. The effort in carrying out this measure in European countries has led to less earnings manipulations and more informative financial statements. 
We derive important implications for policy makers and the corporate sector concerning the linkage between the female board directorship and the earnings management. First, it is strongly recommended the appointment of female directors in the board as a strategy to enhance management decisions and reporting quality. Concerning this, at policy level, the hiring of female workers in senior positions is highly determined by labor market structures and conditions such as the masculinity orientation of each country's culture (Hofstede, 1980). Governments and regulators can take measures to foster a more active participation of female representatives in the corporate sector like generating policies that promote family conciliation and reduce gender discrimination. This sort of measures might remove the 'glass ceiling' in senior positions referred as the invisible or artificial barriers that prevent women from advancing past a certain level (Beaton \& Tougas, 1997; Thiruvadi \& Huang, 2011). Another implication of our works is related with the gender quota laws. Regulation regarding quotas was proven efficient in constraining earnings management. Although European Union Commission compels companies to positively discriminate when hiring new people in directorship positions until quota is reached, there is still aversion in corporations to fulfill such requirements. For instance, previous attempts by the European Union Commission to set a $40.00 \%$ goal for women in senior ranks of companies have been blocked by Germany, the Netherlands and Sweden overs fears that Brussels was overreaching into domestic affairs. Consequently, it is recommended strongly enforce the gender quota laws done by labor inspectorates and articulated by in collective bargaining by the trade unions. The promotion of gender quotas will reduce the gender gap in decision making positions, which eventually will decrease managers' discretionary power. All these measures will promote equality between men and women on boards, contributing to reach one of the founding values of the European Union.

Our results offer consistent perspective about the effectiveness of board gender diversity in constraining earnings management. However, there are many other scopes not analyzed in this work that suggest directions for future research. As suggested by Krishnan and Parsons (2008), earnings quality combines the issues of ethical workplace behavior and women approach toward decision making. Therefore, a future research line can be devoted to the analysis of earnings management in institutional contexts with different ethical standards than in Europe, and where female senior positions in the workplace are clearly underrepresented, such as in Latin America. This would shed additional light on the underexplored impact of women in senior corporate positions on the quality of reported earnings. It would be also worth considering analyzing the association among female directors and their specific attributes (e.g. education, compensation schemes, seniority, women serving in multiple directorships, etc.) and other features of earnings management such as earnings smoothing or loss avoidance as proxies of que quality of financial reporting. This would help to gain a better understanding of the influence of these attributes on the quality of financial information. Additionally, deeper exploration of contextual variables might shed additional light on the impact of gender quotas in executive and board positions. For instance, the comparison of appointment of female directors on a voluntary rather than mandatory basis may indicate how willing the company is to adopt good governance codes to mitigate the opportunistic behavior of its managers. Finally, it would be interesting to study how the effectiveness of the 
board in promoting monitoring of earnings management is molded by women in executive positions. Are female executives better monitored under boards with greater proportion of female directors? Is financial reporting more informative under female managers than male managers? These are unanswered questions to which our study encourages future exploration.

This study is not absent of limitations. Our proxies of earnings management are based on estimations on accruals and other accounting magnitudes. Another measures of earnings manipulation might be employed to reduce any potential bias in the estimations. Additionally, given that our data covers a representative sample of indexed companies in ten European markets, we do not cover the total number of firms in each country. This might lead to a certain skewness in the extrapolation of results to the entire European region given that small and medium size firms are not necessarily considered. Finally, this investigation offers only partial prescription and insight connected to the role of ownership concentration in determining the earnings management. We remain silent regarding the nature of the controlling shareholder (e.g. institutional investor, government, etc.) and how such feature may impact on his/her monitoring role.

\section{Acknowledgements}

The authors are grateful to Ryan McWay, Allison Kittleson, and Javier Lecubarri for their research assistance and the comments from the participants of the Women and Gender Studies Group from Saint Louis University; the seminar participants at the CLADEA-2018 annual meeting in Costa Rica and the Australasian Finance \& Banking Conference-2018 meeting in Australia, Chang-Mo Kang, the Associate Editor, and two anonymous referees for their invaluable comments and suggestions. Professors Paolo Saona and Laura Muro also thank the financial support of the Faculty Research Grant 2017 of Saint Louis University.

\section{References}

Abad, D., Lucas-Pérez, M. E., Minguez-Vera, A., \& Yagüe, J. (2017). Does gender diversity on corporate boards reduce information asymmetry in equity markets? BRQ Business Research Quarterly, 20(3), 192-205. https://doi.org/10.1016/j.brq.2017.04.001

Adams, R. B., \& Ferreira, D. (2009a). Strong managers, weak boards? CESifo Economic Studies, 55(3-4), 482-514. https://doi.org/10.1093/cesifo/ifp023

Adams, R. B., \& Ferreira, D. (2009b). Women in the boardroom and their impact on governance and performance. Journal of Financial Economics, 94(2), 291-309.

https://doi.org/10.1016/j.jineco.2008.10.007

Alonso-Borrego, C., \& Arellano, M. (1999). Symmetrically normalized instrumental variable estimation using panel data. Journal of Business \& Economic Statistics, 17(1), 36-49.

Altman, E. I. (1968). Financial ratios, discriminant analysis and the prediction of corporate bankruptcy. The Journal of Finance, 23(4), 589-609. https://doi.org/10.1111/j.1540-6261.1968.tb00843.x

Arellano, M. (2003). Panel data econometrics. Oxford University Press.

Arellano, M., \& Bond, S. (1991). Some tests of specification for panel data: Monte Carlo evidence and an application to employment equation. The Review of Economic Studies, 58(2), 277-297.

https://doi.org/10.2307/2297968 
Armstrong, C. S., Guay, W. R., \& Weber, J. P. (2010). The role of information and financial reporting in corporate governance and debt contracting. Journal of Accounting and Economics, 50(2-3), 179-234. https://doi.org/10.1016/j.jacceco.2010.10.001

Arun, T. G., Almahrog, Y. E., \& Ali Aribi, Z. (2015). Female directors and earnings management: Evidence from UK companies. International Review of Financial Analysis, 39(Supplement C), 137-146. https://doi.org/10.1016/j.irfa.2015.03.002

Baltagi, B. H. (2013). Econometric analysis of panel data (5th ed.). Chichester, UK: John Wiley \& Sons Ltd.

Barua, A., Davidson, L. F., Rama, D. V., \& Thiruvadi, S. (2010). CFO gender and accruals quality. Accounting Horizons, 24(1), 25-39. https://doi.org/10.2308/acch.2010.24.1.25

Baumgärtner, S. (2006). Measuring the diversity of what? And for what purpose? A conceptual comparison of ecological and economic biodiversity indices. Retrieved from https://papers.ssrn.com/sol3/papers. cfm?abstract_id=894782

Beaton, A. M., \& Tougas, F. (1997). The representation of women in management: the more, the merrier? Personality and Social Psychology Bulletin, 23(7), 773-782. https://doi.org/10.1177/0146167297237010

Beck, N., \& Katz, J. N. (1995). What to do (and not to do) with time-series cross-section data. American Political Science Review, 89(3), 634-647. https://doi.org/10.2307/2082979

Bergström, C., \& Rydqvist, K. (1990). The determinants of corporate ownership: An empirical study on Swedish data. Journal of Banking \& Finance, 14(2), 237-253.

https://doi.org/10.1016/0378-4266(90)90048-7

Berlin, M., \& Loeys, J. (1988). Bond covenants and delegated monitoring. The Journal of Finance, 43(2), 397-412. https://doi.org/10.1111/j.1540-6261.1988.tb03946.x

Bernardi, R. A. (1994). Fraud detection: the effect of client integrity and competence and auditor cognitive style. Auditing: A Journal of Practice \& Theory, 13(1), 68-84.

Bernardi, R. A., \& Arnold, D. F. (1997). An examination of moral development within public accounting by gender, staff level, and firm. Contemporary Accounting Research, 14(4), 653-668. https://doi.org/10.1111/j.1911-3846.1997.tb00545.x

Betz, M., O'Connell, L., \& Shepard, J. M. (1989). Gender differences in proclivity for unethical behavior. Journal of Business Ethics, 8(5), 321-324. https://doi.org/10.1007/BF00381722

Blau, P. M. (1977). Inequality and heterogeneity: a primitive theory of social structure. New York, NY: The Free Press.

Blundell, R., \& Bond, S. (1998). Initial conditions and moment restrictions in dynamic panel data models. Journal of Econometrics, 87(1), 115-143. https://doi.org/10.1016/S0304-4076(98)00009-8

Bond, S. (2002). Dynamic panel data models: A guide to micro data methods and practice. Portuguese Economic Journal, 1(2), 141-162. https://doi.org/10.1007/s10258-002-0009-9

Botsch, E. (2015). The policy on gender equality in Germany. Retrieved from http://www.europarl.europa.eu/RegData/etudes/IDAN/2015/510025/IPOL_IDA(2015)510025_EN.pdf

Byrnes, J. P., Miller, D. C., \& Schafer, W. D. (1999). Gender differences in risk taking: A meta-analysis. Psychological Bulletin, 125(3), 367-383. https://doi.org/10.1037/0033-2909.125.3.367

Chapple, L., Dunstan, K., \& Truong, T. P. (2018). Corporate governance and management earnings forecast behaviour: Evidence from a low private litigation environment. Pacific Accounting Review, 30(2), 222-242. https://doi.org/10.1108/PAR-09-2016-0081

Cohen, D. A., Dey, A., \& Lys, T. Z. (2008). Real and accrual-based earnings management in the pre- and post- sarbanes-oxley periods. The Accounting Review, 83(3), 757-787. https://doi.org/10.2308/accr.2008.83.3.757

Cohn, R. A., Lewellen, W. G., Lease, R. C., \& Schlarbaum, G. G. (1975). Individual investor risk aversion and investment portfolio composition. The Journal of Finance, 30(2), 605-620.

https://doi.org/10.1111/j.1540-6261.1975.tb01834.x 
Dechow, P. M. (1994). Accounting earnings and cash flows as measures of firm performance: The role of accounting accruals. Journal of Accounting and Economics, 18(1), 3-42. https://doi.org/10.1016/0165-4101(94)90016-7

Dechow, P. M., Sloan, R. G., \& Sweeney, A. P. (1995). Detecting earnings management. Accounting Review, 70(2), 193-225.

Estes, R., \& Hosseini, J. (1988). The gender gap on wall street: an empirical analysis of confidence in investment decision making. The Journal of Psychology, 122(6), 577-590. https://doi.org/10.1080/00223980.1988.9915532

Fallan, L. (1999). Gender, exposure to tax knowledge, and attitudes towards taxation; an experimental approach. Journal of Business Ethics, 18(2), 173-184. https://doi.org/10.1023/A:1005711905297

Francis, B., Hasan, I., Park, J. C., \& Wu, Q. (2015). Gender differences in financial reporting decision making: evidence from accounting conservatism. Contemporary Accounting Research, 32(3), 12851318. https://doi.org/10.1111/1911-3846.12098

Gabrielsen, G., Gramlich, J. D., \& Plenborg, T. (2002). Managerial ownership, information content of earnings, and discretionary accruals in a non-US setting. Journal of Business Finance \& Accounting, 29(7-8), 967-988. https://doi.org/10.1111/1468-5957.00457

García, B., \& Gill-de-Albornoz, B. (2007). The effect of the board composition and its monitoring committees on earnings management: Evidence from Spain. Corporate Governance: an International Review, 15(6), 1413-1428. https://doi.org/10.1111/j.1467-8683.2007.00654.x

Gavious, I., Segev, E., \& Yosef, R. (2012). Female directors and earnings management in high-technology firms. Pacific Accounting Review, 24(1), 4-32. https://doi.org/10.1108/01140581211221533

Gormley, T. A., \& Matsa, D. A. (2014). Common errors: how to (and not to) control for unobserved heterogeneity. Review of Financial Studies, 27(2), 617-661. https://doi.org/10.1093/rfs/hht047

Greene, W. (2003). Econometric analysis (5th ed.). New Jersey, USA: Prentice Hall.

Gregorič, A., Oxelheim, L., Randøy, T., \& Thomsen, S. (2017). Resistance to change in the corporate elite: female directors' appointments onto Nordic boards. Journal of Business Ethics, 141(2), 267-287. https://doi.org/10.1007/s10551-015-2703-4

Gul, F. A., Fung, S. Y. K., \& Jaggi, B. (2009). Earnings quality: Some evidence on the role of auditor tenure and auditors' industry expertise. Journal of Accounting and Economics, 47(3), 265-287. https://doi.org/10.1016/j.jacceco.2009.03.001

Gull, A. A., Nekhili, M., Nagati, H., \& Chtioui, T. (2017). Beyond gender diversity: How specific attributes of female directors affect earnings management. The British Accounting Review, 50(3), 255274. https://doi.org/10.1016/j.bar.2017.09.001

Hassan, O. A. G., \& Skinner, F. S. (2016). Analyst coverage: Does the listing location really matter? International Review of Financial Analysis, 46, 227-236. https://doi.org/10.1016/j.irfa.2016.05.008

Hausman, J. A. (1978). Specification tests in econometrics. Econometrica, 46(6), 1251-1271. https://doi.org/10.2307/1913827

Hofstede, G. (1980). Culture's Consequences: International differences in work related values. London: Sage Publications, the International Professional Publisher.

Hsiao, C. (2007). Panel data analysis-advantages and challenges. TEST, 16(1), 1-22. https://doi.org/10.1007/s11749-007-0046-X

Huang, H. H., Chan, M. L., Chang, C. H., \& Wong, J. L. (2012). Is corporate governance related to the conservatism in management earnings forecasts? Emerging Markets Finance \& Trade, 48, 105-121.

Huang, J., \& Kisgen, D. J. (2013). Gender and corporate finance: Are male executives overconfident relative to female executives? Journal of Financial Economics, 108(3), 822-839.

https://doi.org/10.1016/j.jfineco.2012.12.005 
Huse, M., \& Solberg, A. G. (2006). Gender-related boardroom dynamics: How Scandinavian women make and can make contributions on corporate boards. Women in Management Review, 21(2), 113-130. https://doi.org/10.1108/09649420610650693

Jensen, M. C., \& Meckling, W. (1976). Theory of the firm: managerial behaviour, agency cost and ownership structure. Journal of Financial Economics, 3(4), 305-360.

https://doi.org/10.1016/0304-405X(76)90026-X

Jones, J. J. (1991). Earnings management during import relief investigations. Journal of Accounting Research, 29(2), 193-228. https://doi.org/10.2307/2491047

Kaufmann, D., Kraay, A., \& Mastruzzi, M. (2011). The worldwide governance indicators: methodology and analytical issues. Hague Journal of the Rule of Law, 3(2), 220-246. https://doi.org/10.1017/S1876404511200046

Krishnan, G. V., \& Parsons, L. M. (2008). Getting to the bottom line: an exploration of gender and earnings quality. Journal of Business Ethics, 78(1), 65-76. https://doi.org/10.1007/s10551-006-9314-Z

Kyaw, K., Olugbode, M., \& Petracci, B. (2015). Does gender diverse board mean less earnings management? Finance Research Letters, 14, 135-141. https://doi.org/10.1016/j.frl.2015.05.006

La Porta, R., Lopez-De-Silanes, F., \& Shleifer, A. (1999). Corporate ownership around the world. The Journal of Finance, 54(2), 471-517. https://doi.org/10.1111/0022-1082.00115

La Porta, R., Lopez-De-Silanes, F., Shleifer, A., \& Vishny, R. (1997). Legal determinants of external finance. The Journal of Finance, 52(3), 1131-1150. https://doi.org/10.1111/j.1540-6261.1997.tb02727.x

La Porta, R., Lopez-De-Silanes, F., Shleifer, A., \& Vishny, R. (1998). Law and finance. The Journal of Political Economy, 106(6), 1113-1155. https://doi.org/10.1086/250042

Leuz, C., Nanda, D., \& Wysocki, P. D. (2003). Earnings management and investor protection: An international comparison. Journal of Financial Economics, 69(3), 505-527. https://doi.org/10.1016/S0304-405X(03)00121-1

Lombardo. (2015). Gender equality policies in Spain - update. Retrieved from http://www.europarl. europa.eu/RegData/etudes/STUD/2016/583112/IPOL_STU(2016)583112_EN.pdf

López, F., \& Saona, P. (2005). Earnings management and internal mechanisms of corporate governance: Empirical evidence from Chilean firms. Corporate Ownership \& Control, 3(1), 17-29.

Martín-Ugedo, J. F., \& Minguez-Vera, A. (2014). Firm performance and women on the board: evidence from Spanish small and medium-sized enterprises. Feminist Economics, 20(3), 136-162. https://doi.org/10.1080/13545701.2014.895404

Nielsen, S., \& Huse, M. (2010). The contribution of women on boards of directors: going beyond the surface. Corporate Governance: an International Review, 18(2), 136-148. https://doi.org/10.1111/j.1467-8683.2010.00784.x

Numhauser-Henning, A. (2015). The policy on gender equality in Sweden. Retrieved from http://www. europarl.europa.eu/RegData/etudes/STUD/2015/510011/IPOL_STU(2015)510011_EN.pdf

Prat, B., \& Mueller, H. (2016). Board-level gender quotas in the UK, France and Germany. News, 14(1), 1-17.

Pucheta Martínez, M. C., Bel Oms, I., \& Olcina Sempere, G. (2016). Corporate governance, female directors and quality of financial information. Business Ethics: A European Review, 25(4), 363-385. https://doi.org/10.1111/beer.12123

Reed, W. R., \& Webb, R. (2010). The PCSE estimator is good -- just not as good as you think. Journal of Time Series Econometrics, 2(1). https://doi.org/10.2202/1941-1928.1032

Riley Jr., W. B., \& Chow, K. V. (1992). Asset allocation and individual risk aversion. Financial Analysts Journal, 48(6), 32-37. https://doi.org/10.2469/faj.v48.n6.32 
Roberts, M. R., \& Whited, T. M. (2013). Endogeneity in empirical corporate finance. In G. M. Constantinides, M. Harris, \& R. Stulz (Eds.), Handbook of the economics of finance (Vol. 2, Part A, pp. 493-572). Elsevier.

Ruegger, D., \& King, E. W. (1992). A study of the effect of age and gender upon student business ethics. Journal of Business Ethics, 11(3), 179-186. https://doi.org/10.1007/BF00871965

Saona, P., \& Muro, L. (2017). Firm- and Country-level attributes as determinants of earnings management: an analysis for Latin American firms. Emerging Markets Finance and Trade, 54(12), 27362764. https://doi.org/10.1080/1540496X.2017.1410127

Sexton, D. L., \& Bowman-Upton, N. (1990). Female and male entrepreneurs: Psychological characteristics and their role in gender-related discrimination. Journal of Business Venturing, 5(1), 29-36. https://doi.org/10.1016/0883-9026(90)90024-N

Shannon, C. E. (1948). A mathematical theory of communication. Bell System Technical Journal, 27(3), 379-423. https://doi.org/10.1002/j.1538-7305.1948.tb01338.x

Sila, V., Gonzalez, A., \& Hagendorff, J. (2016). Women on board: Does boardroom gender diversity affect firm risk? Journal of Corporate Finance, 36(Supplement C), 26-53. https://doi.org/10.1016/j.jcorpfin.2015.10.003

Srinidhi, B. I. N., Gul, F. A., \& Tsui, J. (2011). Female directors and earnings quality. Contemporary Accounting Research, 28(5), 1610-1644. https://doi.org/10.1111/j.1911-3846.2011.01071.x

Storvik, A., \& Teigen, M. (2010). Women on board: the Norwegian experience. Retrieved from https:// library.fes.de/pdf-files/id/ipa/07309.pdf

Thiruvadi, S., \& Huang, H. W. (2011). Audit committee gender differences and earnings management. Gender in Management: an International Journal, 26(7), 483-498. https://doi.org/10.1108/17542411111175469

Wintoki, M. B., Linck, J. S., \& Netter, J. M. (2012). Endogeneity and the dynamics of internal corporate governance. Journal of Financial Economics, 105(3), 581-606. https://doi.org/10.1016/j.jfineco.2012.03.005

Ye, K., Zhang, R., \& Rezaee, Z. (2010). Does top executive gender diversity affect earnings quality? A large sample analysis of Chinese listed firms. Advances in Accounting, 26(1), 47-54.

https://doi.org/10.1016/j.adiac.2010.02.008 